\title{
2-(2-(2-Hydroxybenzyliden) Hydrazinyl)-2-Oxo-N-(Pyridine-2-Yl) Acetamide Complexes: Synthesis, Characterization and Biological Studies
}

Yasmeen Gaber Abou El-Reash, Rania Zaky* and Mahmoud Abbas Yaseen

Department of Chemistry, Faculty of Science, Mansoura University, Mansoura, Egypt

\begin{abstract}
2-(2-(2-hydroxybenzyliden) hydrazinyl)-2-oxo-N-(pyridine-2-yl) acetamide complexes of $\mathrm{Ni}(\mathrm{II})$ and $\mathrm{Co}$ (II) prepared. The proposed structures proved based on elemental, DFT, and spectral analysis. The DNA binding affinity and MIC activity against Gram-positive, Gram-negative bacteria, pathogenic C. albicans and A. flavus fungal strain tested.
\end{abstract}

\section{Keywords: Hydrazones; DFT; DND; Potentiometry}

\section{Introduction}

Hydrazones are versatile ligands and possessing an azomethine $-\mathrm{NHN}=\mathrm{CH}-$ proton groups. They can be described by the following general structure $\mathrm{R}_{2} \mathrm{C}=\mathrm{NNR}_{2}$. Hydrazone ligands and their metal complexes were attracted many authors because of their varied applications in biological, pharmaceutical, analytical, catalytic [1-5] and industrial fields. Hydrazones and their coordination compounds play important roles in treatment of different diseases. Hydrazones considered as an significant class of compounds with wide importance due to their various biological applications such as anticonvulsant, analgesic, anti-inflammatory, antidepressant, antimalarial, antiplatelet, antimycobacterial, antimicrobial, antiviral, anticancer, antidiabetic, vasodilator, anti-HIV, anthelmintic, and trypanocidal activities [614]. This work targets the synthesize and characterization $\mathrm{Co}(\mathrm{II})$ and $\mathrm{Ni}$ (II) complexes of 2-(2-(2-hydroxybenzyliden) hydrazinyl)-2-oxo-N(pyridine-2-yl) acetamid $\left(\mathrm{H}_{2} \mathrm{~L}\right)$. The geometry and modes of chelation of complexes were discussed based on the resulted (DFT) quantum calculations, the magnetic moment, the different spectroscopic methods $\left({ }^{1} \mathrm{H}\right.$ and ${ }^{13} \mathrm{C}$-NMR, UV-visible, IR, EI-mass). Moreover, the thermal decomposition steps were studied and both the kinetics and thermodynamic factors were determined using Coats-Redfern and Horowitz-Metzger models. In addition, potentiometric titrations were done in $50 \%$ DMSO-water mixture at various temperatures (298, 308 and $318 \mathrm{~K}$ ) respectively. Moreover, their Minimum inhibitory concentration (MIC) and DNA-binding affinity assay were tested.

\section{Experimental Methods}

\section{Instrumentation}

$\left(\mathrm{C}, \mathrm{H}\right.$ and $\mathrm{N}$ ) percent presented in the prepared ligand $\left(\mathrm{H}_{2} \mathrm{~L}\right)$ and complexes were detected using a Perkin-Elmer 2400 series II analyzer, while chloride and metal contents determined using standard methods reported previously [15]. A thermogravimetric analyzer (TGA-50H) from Shimadzu, Japan, used for both thermogravimetric (TGA) and differential thermal analysis (DTA) measurements with a heating rate of $10^{\circ} \mathrm{C} / \mathrm{min}$ on at temperature range $\left(20-800^{\circ} \mathrm{C}\right)$ and nitrogen flow rate of $15 \mathrm{ml} / \mathrm{min}$. A Sherwood Magnetic Balance was utilized to measure the magnetic susceptibility of solid complexes. A Mattson 5000 FTIR spectrophotometer was used to analyze the prepared ligand and complexes under range of $\left(4000-400 \mathrm{~cm}^{-1}\right)$ in $\mathrm{KBr}$ discs. While; the electronic spectra of complexes (in DMSO solution) was recorded using a Perkin Elmer Lamda $25 \mathrm{UV} / \mathrm{Vis}$ Spectrophotometer. ${ }^{1} \mathrm{H}$, ${ }^{13} \mathrm{C}$-NMR measurements were done on Mercury and Gemini $400 \mathrm{MHZ}$ spectrometer at room temperature in $\mathrm{d}_{6}$-DMSO. $\mathrm{pH}$ meter HANNA -8519 , Italy used in all $\mathrm{pH}$ - metric measurements.

\section{Synthesis}

\section{Preparation of ligand $\left(\mathrm{H}_{2} \mathrm{~L}\right)$}

Preparation of ethyl 2-oxo-2-(pyridin-2-ylamino) acetate: Ethyl 2-oxo-2-(pyridin-2-ylamino) acetate were prepared by adding of diethyl oxalate $(1 \mathrm{mmol})$ dissolved in xylene to 2 -amino pyridine (1 $\mathrm{mmol}$ ) dissolved in xylene with stirring followed by reflux with stirring for $3 \mathrm{hr}$. Let the resulted product to cool then filtered off, washed by ether and at the end dried over anhydrous calcium chloride in a vacuum desiccator. The product is yellow color powder with m.p. $\left(180^{\circ} \mathrm{C}\right)$.

Preparation of 2-hydrazinyl-2-oxo- $\mathrm{N}$-(pyridin-2-yl) acetamide: 2-hydrazinyl-2-oxo-N-(pyridin-2-yl) acetamide were prepared by adding of hydrazine hydrate $(1 \mathrm{mmol})$ dissolved in xylene to ethyl 2-oxo-2-(pyridin-2-ylamino) acetate $(1 \mathrm{mmol})$ dissolved in xylene with stirring followed by reflux with stirring for $3 \mathrm{hr}$. Let the resulted product to cool then filtered off, washed by ether and at the end dried in a vacuum desiccator over anhydrous calcium chloride. The resulted ligand is a yellow color powder with m.p $\left(195^{\circ} \mathrm{C}\right)$.

Preparation of ligand $\left(\mathrm{H}_{2} L\right):$ 1:1 molar ratio of 2-hydrazinyl2-oxo-N-(pyridin-2-yl) acetamide and 2-hydroxybenzaldehyde (salicylaldehyde) were mixed in a hot ethanolic solution with few drops of glacial acetic acid. The mixture was refluxed for $4 \mathrm{~h}$ under magnetic stirring. The formed products were separated by filtration, and then recrystallized from ethanol absolute. Finally, the resulted ligand was dried for $36 \mathrm{~h}$ in a vacuum desiccator, then investigated by TLC, elemental analysis (C, $\mathrm{H}$ and $\mathrm{N}$ ), and spectroscopic methods (IR, UVVis., ${ }^{1} \mathrm{H}$ NMR, ${ }^{13} \mathrm{C}$ NMR and EI-mass).

Preparation of solid complexes: All the complexes were prepared by refluxing $1 \mathrm{mmol}$ of ligand under investigation with $1 \mathrm{mmol}$ of the metal salt, $\mathrm{NiCl}_{2} \cdot 6 \mathrm{H}_{2} \mathrm{O}$, and $\mathrm{CoCl}_{2} \cdot 6 \mathrm{H}_{2} \mathrm{O}$ in an ethanolic solution on a water bath for 2-3 h. The resulting solid complexes filtered off, washed several times with absolute ethanol and finally dried.

*Corresponding author: Rania Zaky, Department of Chemistry, Faculty of Science, Mansoura University, Mansoura, Egypt, Tel: +20502383781; E-mail: rania.zaky@yahoo.com

Received November 01, 2016; Accepted December 05, 2016; Published December 08, 2016

Citation: El-Reash YGA, Zaky R, Yaseen MA (2016) 2-(2-(2-Hydroxybenzyliden) Hydrazinyl)-2-Oxo-N-(Pyridine-2-YI) Acetamide Complexes: Synthesis, Characterization and Biological Studies. Chem Sci J 7: 145. doi: 10.4172/2150-3494.1000145

Copyright: (C) 2016 El-Reash YGA, et al. This is an open-access article distributed under the terms of the Creative Commons Attribution License, which permits unrestricted use, distribution, and reproduction in any medium, provided the original author and source are credited. 
Citation: El-Reash YGA, Zaky R, Yaseen MA (2016) 2-(2-(2-Hydroxybenzyliden) Hydrazinyl)-2-Oxo-N-(Pyridine-2-Yl) Acetamide Complexes: Synthesis, Characterization and Biological Studies. Chem Sci J 7: 145. doi: 10.4172/2150-3494.1000145

Page 2 of 10

\section{Molecular modelling}

Cluster calculations were evaluated using $\mathrm{DMOL}^{3}$ program [16] in Materials Studio package [17]. This program designed for the calculations of density functional theory (DFT) over a large scale. Moreover, DFT method was applied to calculate the semi-core pseudopods (dspp) by using the double numerical basis sets plus polarization functional (DNP). Delley et al. revealed that the DNP basis sets are more precise than Gaussian basis sets of the same size $[18,19]$. Lately; the RPBE basis sets are the best exchange-correlation functional $[20,21]$. It utilized for the determination of both the exchange and correlation effects of electrons based on the generalized gradient approximation (GGA). The geometric design predicted without any symmetry restriction.

\section{pH-metric study}

Potentiometric titrations were done at 298,308 and $318^{\circ} \mathrm{K}$ in a mixture of dioxane-water $50 \%(\mathrm{v} / \mathrm{v})$. All resulted values were adjusted using Van Uitert and Hass relation [22]:

$$
-\log \left[\mathrm{H}^{+}\right]=\mathrm{B}+\log \mathrm{U}_{\mathrm{H}}^{0}+\log \gamma_{ \pm}
$$

Where $\log \mathrm{U}_{\mathrm{H}}^{0}$ and $\log \gamma_{ \pm}$are the correction factors for the solvent composition and ionic strength, respectively and $\mathrm{B}$ is the reading.

In the experiments; the following mixtures were titrated against standardized free carbonate $\mathrm{NaOH}$ solution $\left(8.5 \times 10^{-3} \mathrm{~mol} \mathrm{~L}^{-1}\right)$ in $50 \%$ $(\mathrm{v} / \mathrm{v}) \mathrm{DMSO}-$ water at constant ionic strength $\left(1 \mathrm{~mol} \mathrm{~L}^{-1} \mathrm{KCl}\right.$ solution $)$ The solution mixtures (i-iii) were prepared as follows:

i) $1.25 \mathrm{ml} \mathrm{HCl}\left(1.12 \times 10^{-2} \mathrm{M}\right)+1.25 \mathrm{ml} \mathrm{KCl}(1 \mathrm{M})+12.5 \mathrm{ml}$ DMSO $+10 \mathrm{ml}$ bidistilled $\mathrm{H}_{2} \mathrm{O}$.

ii) $1.25 \mathrm{ml} \mathrm{HCl}\left(1.12 \times 10^{-2} \mathrm{M}\right)+1.25 \mathrm{ml} \mathrm{KCl}(1 \mathrm{M})+2.5 \mathrm{ml}\left(5 \times 10^{-3}\right.$ M) $\mathrm{H}_{2} \mathrm{PET}+10 \mathrm{ml} \mathrm{DMSO}+10 \mathrm{ml}$ bidistilled $\mathrm{H}_{2} \mathrm{O}$.

iii) $1.25 \mathrm{ml} \mathrm{HCl}\left(1.12 \times 10^{-2} \mathrm{M}\right)+1.25 \mathrm{ml} \mathrm{KCl}(1 \mathrm{M})+2.5 \mathrm{ml}\left(5 \times 10^{-3}\right.$ M) $\mathrm{H}_{2} \mathrm{PET}+10 \mathrm{ml} \mathrm{DMSO}+0.5 \mathrm{ml}$ metal ion $\left(\mathrm{M}^{\mathrm{n}+}\right)\left(5 \times 10^{-3} \mathrm{M}\right)$, [where $\left.\mathrm{M}^{\mathrm{n}+}=\mathrm{Co}(\mathrm{II})\right]+9.5 \mathrm{ml}$ bidistilled $\mathrm{H}_{2} \mathrm{O}$.

The total volume attuned to $25 \mathrm{ml}$ by DMSO in each prepared mixture.

\section{Biological activity}

Minimum Inhibitory Concentration (MIC): The biological activities for the prepared ligand and its solid complexes were examined against diverse types of strains isolated from animal byproducts. These strains were suspected to be the main reason for food intoxication in human. Staphylococcus aureus, Bacillus subtilis are examples for gram positive bacteria and Escherichia coli, Pseudomonas aeuroginosa are gram negative bacetria. All samples were tested in a Muller Hinton agar medium (Oxoid). Also, the anti-fungal activity for these compounds against (Candida albicans and Aspergillus flavus) was checked in Sabouraud dextrose agar medium (Oxoid). Ampicillin as anti-bacterial and Colitrimazole Fluconazole as anti-fungal were used as standard materials.

MIC [23] of the respective compounds were measured by agar streak dilution method. All steps of the experiments were carried out as reported previously [24].

Colorimetric assay for compounds that bind DNA: A suspended solution of $20 \mathrm{mg}$ of DNA methyl green was prepared in $100 \mathrm{ml}$ of Tris$\mathrm{HCl}(0.05 \mathrm{M})$, buffered at $\mathrm{pH} 7.5$ and contains $7.5 \mathrm{mM} \mathrm{MgSO}_{4}$. This mixture was stirred for $24 \mathrm{~h}$ at $37^{\circ} \mathrm{C}$. In an ependoff tubes, $10,100,1000$ $\mathrm{mg}$ of test samples dissolved in ethanol were prepared, then solvent was removed under vacuum, and $200 \mu \mathrm{l}$ of the DNA/methyl green solution were added to all tubes. All samples were incubated for $24 \mathrm{~h}$ in the dark at ambient temperature, and then the absorbance values for the samples were evaluated at $642.5-645 \mathrm{~nm}$. Reading values were corrected per the initial absorbance of the untreated standard [25].

\section{Results and Discussion}

\section{Infrared and ${ }^{1} \mathrm{H},{ }^{13} \mathrm{C}$ NMR, mass spectra of $\mathrm{H}_{2} \mathrm{~L}$ and its metal complexes}

The Infrared spectrum of $\mathrm{H}_{2} \mathrm{~L}$ (Structure 1) shown seven peaks at $3345,3320,3266,1708,1672,1607$ and $785 \mathrm{~cm}^{-1}$ which attributed to $v(\mathrm{OH})[8,26], v(\mathrm{NH})_{1}, v(\mathrm{NH})_{2}, v\left(\mathrm{CH}_{2}\right)$ [27] $v(\mathrm{C}=\mathrm{O})_{1}, \mathrm{v}(\mathrm{C}=\mathrm{O})_{2}[6]$, $v(\mathrm{C}=\mathrm{N})$ and $\delta(\mathrm{C}=\mathrm{N})$, respectively. The ${ }^{1} \mathrm{H}-\mathrm{NMR}$ spectrum of $\mathrm{H}_{2} \mathrm{~L}$ was recorded in DMSO (Figure 1). The ligand $\left(\mathrm{H}_{2} \mathrm{~L}\right)$ display three signals at $12.62,11.21$ and $10.82 \mathrm{ppm}$ can be attributed to the protons of $(\mathrm{OH})$, $(\mathrm{NH})_{1}$ and $(\mathrm{NH})_{2}$, respectively which they are disappeared on adding of $\mathrm{D}_{2} \mathrm{O}$ (Figure 2). The various signals detected in the region of (6.718.99) $\mathrm{ppm}$ are assigning to the present aromatic and pyridine ring protons. The sharp signal observed $3.46 \mathrm{ppm}$ was assigned to protons of $-\mathrm{N}=\mathrm{C} \underline{\mathrm{H}}-$.

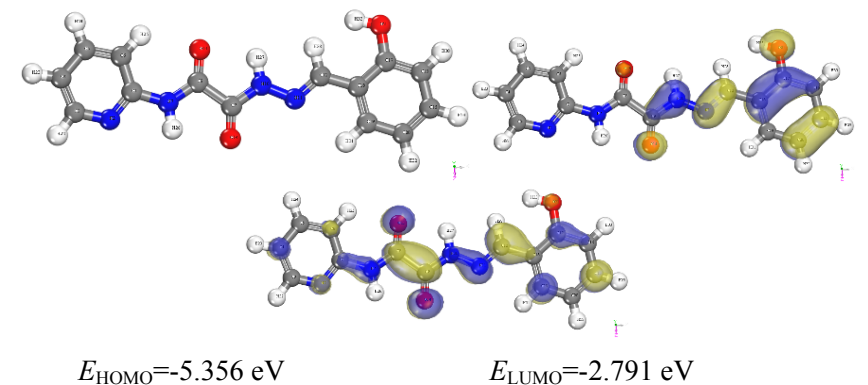

Structure 1: (a) Optimized molecular structure of $\mathrm{H}_{2} \mathrm{~L}$, (b) HOMO and (c) LUMO.
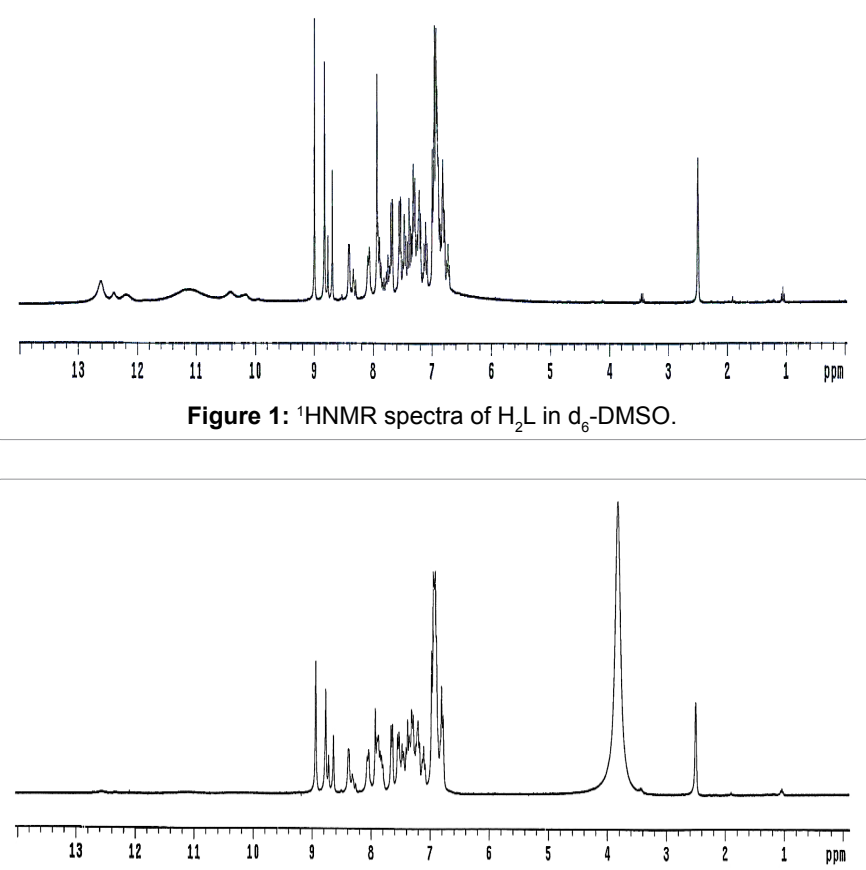

Figure 2: ${ }^{1} \mathrm{HNMR}$ spectra of $\mathrm{H}_{2} \mathrm{~L}$ in $\mathrm{d}_{6}$-DMSO with addition of $\mathrm{D}_{2} \mathrm{O}$. 
Citation: El-Reash YGA, Zaky R, Yaseen MA (2016) 2-(2-(2-Hydroxybenzyliden) Hydrazinyl)-2-Oxo-N-(Pyridine-2-Yl) Acetamide Complexes: Synthesis, Characterization and Biological Studies. Chem Sci J 7: 145. doi: 10.4172/2150-3494.1000145

Page 3 of 10

The ${ }^{13} \mathrm{C}$ NMR spectrum of $\mathrm{H}_{2} \mathrm{~L}$ was recorded in DMSO (Figure 3). The signals for the $(\mathrm{C}=\mathrm{O})_{1},(\mathrm{C}=\mathrm{O})_{2}$, and $(\mathrm{C}=\mathrm{N})$ were displayed at downfield position $(158.6,162.7)$, and (149.8), respectively $[27,28]$.

In the IR spectra of $\mathrm{Ni}(\mathrm{II})$ and $\mathrm{Co}(\mathrm{II})$ complexes (Structures 2 and 3), $\mathrm{H}_{2} \mathrm{~L}$ behaves as binegative tetradentate via $(\mathrm{C}=\mathrm{N})_{\mathrm{az}}$, both $(\mathrm{C}-\mathrm{O})$ enolized with deprotonation and $(\mathrm{OH})_{\text {phenolic }}$ This suggestion indicated by:

i) $v(\mathrm{C}=\mathrm{N})_{\mathrm{az}}$ shifted to a lower wavenumber.

ii) $v(\mathrm{C}=\mathrm{O})$ disappeared with simultaneous appearance of new bands attributed to $v(\mathrm{C}=\mathrm{N})^{*}$ and $v(\mathrm{C}-\mathrm{O})$ [29-32].

iii) $v(\mathrm{OH})$ shifted to a higher wavenumber.

iv) New bands appeared at (513 and 541) and (454 and 459) $\mathrm{cm}^{-1}$ which attributable to $(\mathrm{M}-\mathrm{O})$ and $(\mathrm{M}-\mathrm{N})[26]$, respectively.

\section{Magnetic properties and electronic spectra}

The functions for all the spectral bands for the prepared ligand and its complexes in DMSO and the magnetic moments are compiled

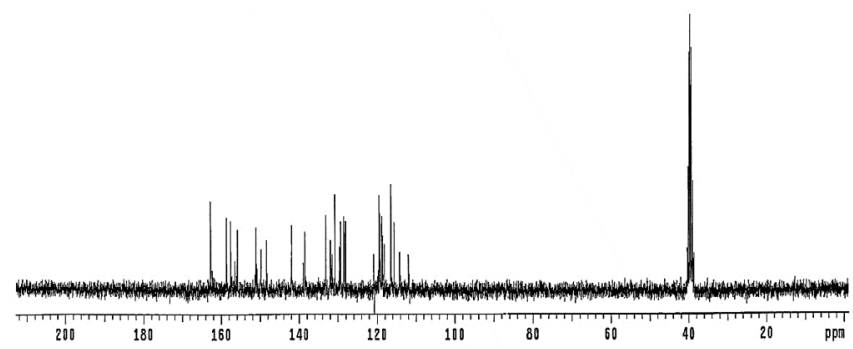

Figure 3: ${ }^{13} \mathrm{CNMR}$ spectra of $\mathrm{H}_{2} \mathrm{~L} \mathrm{~d}_{6}$-DMSO. The mass spectrum of $\mathrm{H}_{2} \mathrm{~L}$ is given in Figure 4 shows the molecular ion peak for $\mathrm{H}_{2} \mathrm{~L}$ at $\mathrm{m} / \mathrm{z}=284.20(4.05 \%)$ corresponding to $\left(\mathrm{C}_{14} \mathrm{H}_{12} \mathrm{~N}_{4} \mathrm{O}_{3}\right)$ [29]. The fragmentation path of $\mathrm{H}_{2} \mathrm{~L}$ is given in Ref. $[30,31]$.

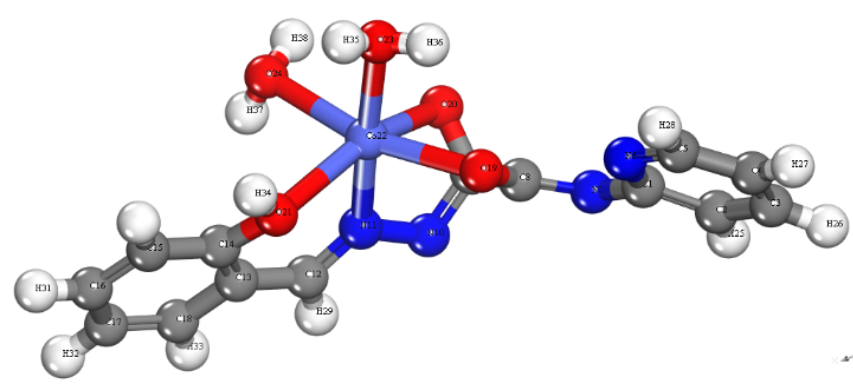

Structure 2: Optimized molecular structure of $\left[\mathrm{Co}(\mathrm{L})\left(\mathrm{H}_{2} \mathrm{O}\right)_{2}\right] \cdot 2 \mathrm{H}_{2} \mathrm{O}$

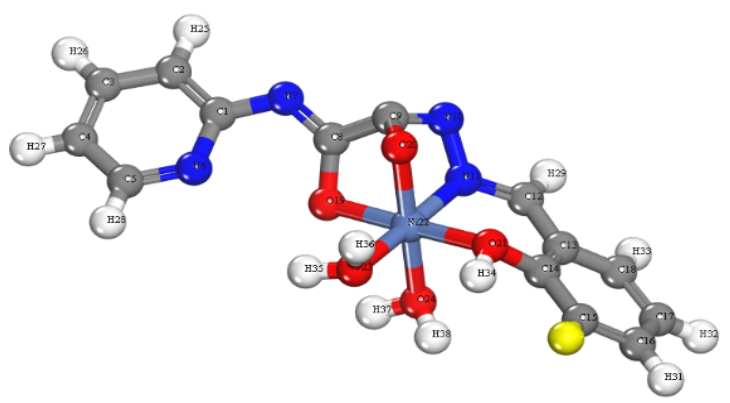

Structure 3: Optimized molecular structure of $\left[\mathrm{Ni}(\mathrm{L})\left(\mathrm{H}_{2} \mathrm{O}\right)_{2}\right] \cdot 2 \mathrm{H}_{2} \mathrm{O}$.

\begin{tabular}{|c|c|c|c|c|c|}
\hline Compound & Band position, $\mathbf{c m}^{-1}$ & $\begin{array}{c}\mathbf{D q} \\
\left(\mathbf{c m}^{-1}\right)\end{array}$ & $\begin{array}{c}\mathbf{B} \\
\left(\mathbf{c m}^{-1}\right)\end{array}$ & $\boldsymbol{\beta}$ & $\boldsymbol{\mu}_{\text {eff }}$ (B.M) \\
\hline $\mathrm{H}_{2} \mathrm{~L}$ & $32787,27473,25510$ & - & - & - & - \\
\hline$\left[\mathrm{Co}(\mathrm{L})\left(\mathrm{H}_{2} \mathrm{O}\right)_{2}\right] \cdot 2 \mathrm{H}_{2} \mathrm{O}$ & $28249,23148,17136,14084$ & 964 & 916 & 0.99 & 5.04 \\
\hline$\left[\mathrm{Ni}(\mathrm{L})\left(\mathrm{H}_{2} \mathrm{O}\right)_{2}\right] \cdot 2 \mathrm{H}_{2} \mathrm{O}$ & $31646,27624,26667,17391$ & 1067 & 762 & 0.73 & 3.30 \\
\hline
\end{tabular}

Table 1: Electronic spectral data of $\mathrm{H}_{2} \mathrm{~L}$ and its complexes.

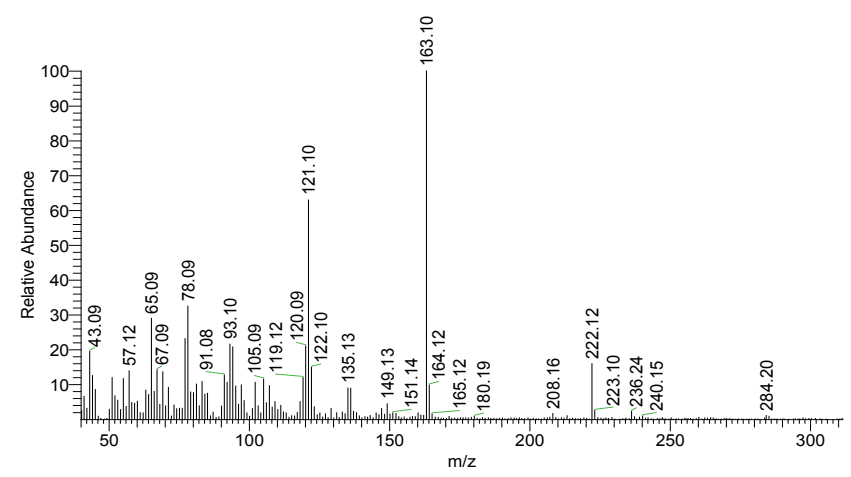

Figure 4: Mass spectrum of $\mathrm{H}_{2} \mathrm{~L}$.

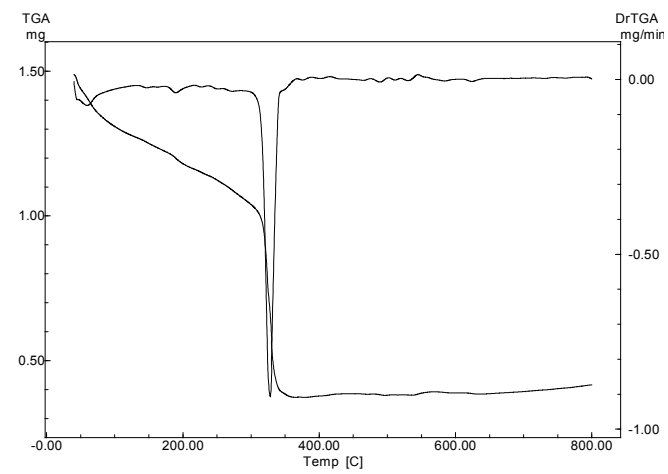

Figure 5: Thermal analysis curves (TGA, DTG) of $\left[\mathrm{Ni}(\mathrm{L})\left(\mathrm{H}_{2} \mathrm{O}\right)_{2}\right] \cdot 2 \mathrm{H}_{2} \mathrm{O}$ complex.

(Table 1). The ligand $\left(\mathrm{H}_{2} \mathrm{~L}\right)$ showed two main absorption bands at 32787 and $27473 \mathrm{~cm}^{-1}$ assigned to $\pi-\pi^{*}$ and one obivious band at 25510 $\mathrm{cm}^{-1}$ attributed to $\mathrm{n}-\pi^{*}$ of both $\mathrm{C}=\mathrm{O}$ and $\mathrm{C}=\mathrm{N}$ groups $[33,34]$.

For $\left[\mathrm{Co}(\mathrm{L})\left(\mathrm{H}_{2} \mathrm{O}\right)_{2}\right] \cdot 2 \mathrm{H}_{2} \mathrm{O}$ complex, two bands were observed at 14084 and $17136 \mathrm{~cm}^{-1}$ assignable to ${ }^{4} \mathrm{~T}_{1 \mathrm{~g}}(\mathrm{~F}) \rightarrow{ }^{4} \mathrm{~A}_{2 \mathrm{~g}}(\mathrm{~F})\left(v_{2}\right)$ and ${ }^{4} \mathrm{~T}_{1 \mathrm{~g}}(\mathrm{~F}) \rightarrow{ }^{4} \mathrm{~T}_{1 \mathrm{~g}}(\mathrm{P})\left(v_{3}\right)$ transitions respectively, which agree with the high spin octahedral $\mathrm{Co}$ (II) $[35,36]$. Moreover, the ligand field parameters, $\mathrm{D}_{\mathrm{q}}, \mathrm{B}$ and $\beta(964,916$ and 0.99$)$ can be considered as an evidence for the proposed geometry. As well, the value of the magnetic moments ( $\mu$ eff.=5.04 BM) was consistent with the proposed octahedral geometry.

Furthermore, in $\left[\mathrm{Ni}(\mathrm{L})\left(\mathrm{H}_{2} \mathrm{O}\right)_{2}\right] \cdot 2 \mathrm{H}_{2} \mathrm{O}$ complex; two bands appeared at 17391 and $26667 \mathrm{~cm}^{-1}$ that are assignable to ${ }^{3} \mathrm{~A}_{2 \mathrm{~g}}(\mathrm{~F}) \rightarrow^{3} \mathrm{~T}_{1 \mathrm{~g}}(\mathrm{~F})\left(v_{2}\right)$ and ${ }^{3} \mathrm{~A}_{2 \mathrm{~g}}(\mathrm{~F}) \rightarrow{ }^{3} \mathrm{~T}_{2 \mathrm{~g}}(\mathrm{P})\left(v_{3}\right)$ transitions. These transitions are distinguishing for the octahedral $\mathrm{Ni}(\mathrm{II})$ complexes [37] and the calculated ligand field factors, $D_{c}, B$ and $\beta(1067,762$ and 0.73$)$ and magnetic moments value ( $\mu$ eff. $=3.3 \mathrm{BM}$ ) support the supposed geometry. The position of $v_{1}(7902$ $\mathrm{cm}^{-1}$ ) was calculated theoretically [28].

\section{Thermogravimetric studies}

The TG and DTA curves for the decomposition of $\mathrm{Ni}(\mathrm{II})$-complex were depicted in Figures 4 and 5. The obtained results approved the proposed formulae. Where, the complex decomposed in three main 
Citation: El-Reash YGA, Zaky R, Yaseen MA (2016) 2-(2-(2-Hydroxybenzyliden) Hydrazinyl)-2-Oxo-N-(Pyridine-2-Yl) Acetamide Complexes: Synthesis, Characterization and Biological Studies. Chem Sci J 7: 145. doi: 10.4172/2150-3494.1000145

steps. The primary step implied losing hydrated water molecules at 40 $76^{\circ} \mathrm{C}$, followed by the losing coordinated water at $76-200^{\circ} \mathrm{C}$. Then, the deligation began at a temperature range of $200-800^{\circ} \mathrm{C}$ and at the end metal oxide was formed.

Kinetic data: The kinetic parameters were calculated by using nonisothermal methods of decomposition steps. The rate of degradation $(\mathrm{d} \alpha / \mathrm{dt})$ is a linear function of rate constant $(\mathrm{k})$ and function of conversion ( $\alpha$ ) and can be expressed as follow [a]:

$\mathrm{d} \alpha / \mathrm{dt}=\mathrm{K}(\mathrm{T}) f(\alpha)$

$\mathrm{k}$ can be calculated by the Arrhenius equation:

$$
\mathrm{K}=\mathrm{Ae}^{(-\mathrm{E} / \mathrm{RT})}
$$

Where $\mathrm{R}$ is the gas constant, $\mathrm{E}$ is the activation energy and $\mathrm{A}$ is the pre-exponential factor.

By substituting Eq. (2) into Eq. (1):
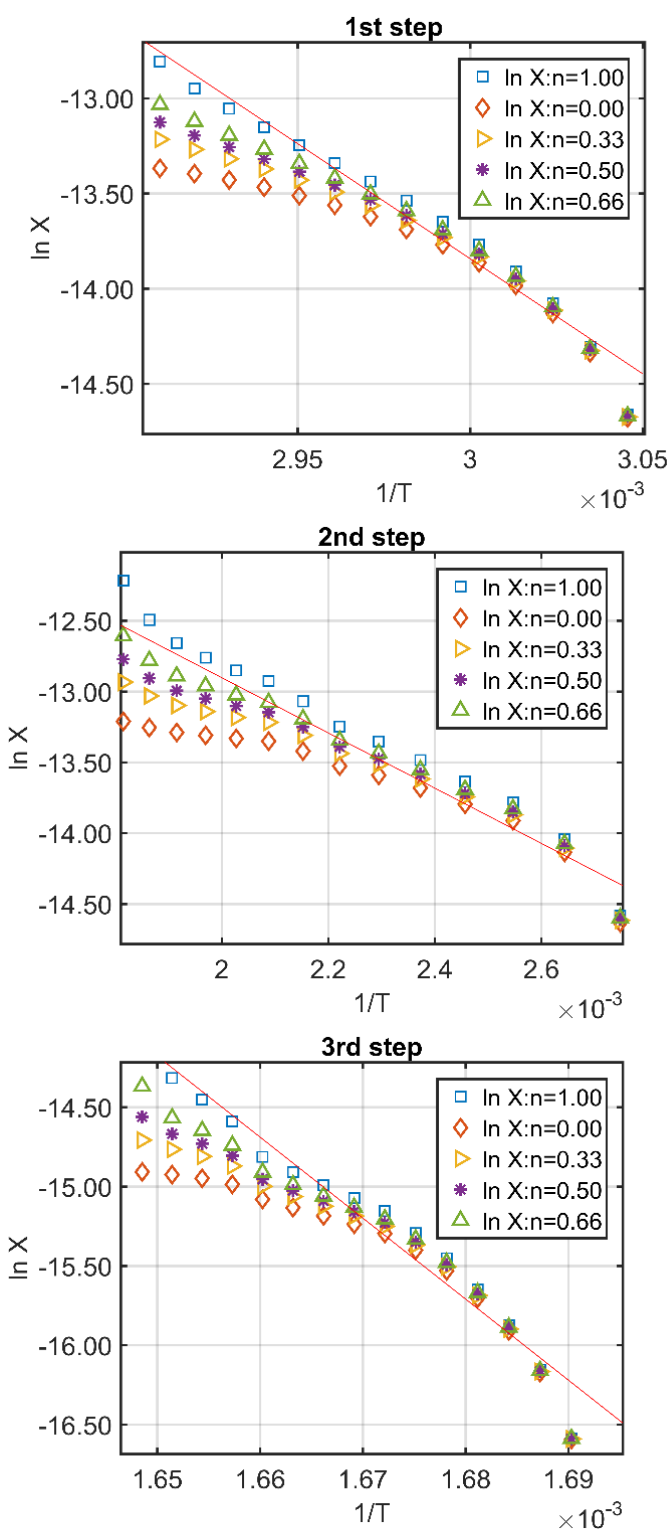

Figure 6: Coats-Redfern plots of $\left[\mathrm{Ni}(\mathrm{L})\left(\mathrm{H}_{2} \mathrm{O}\right)_{2}\right] \cdot 2 \mathrm{H}_{2} \mathrm{O}$ complex.
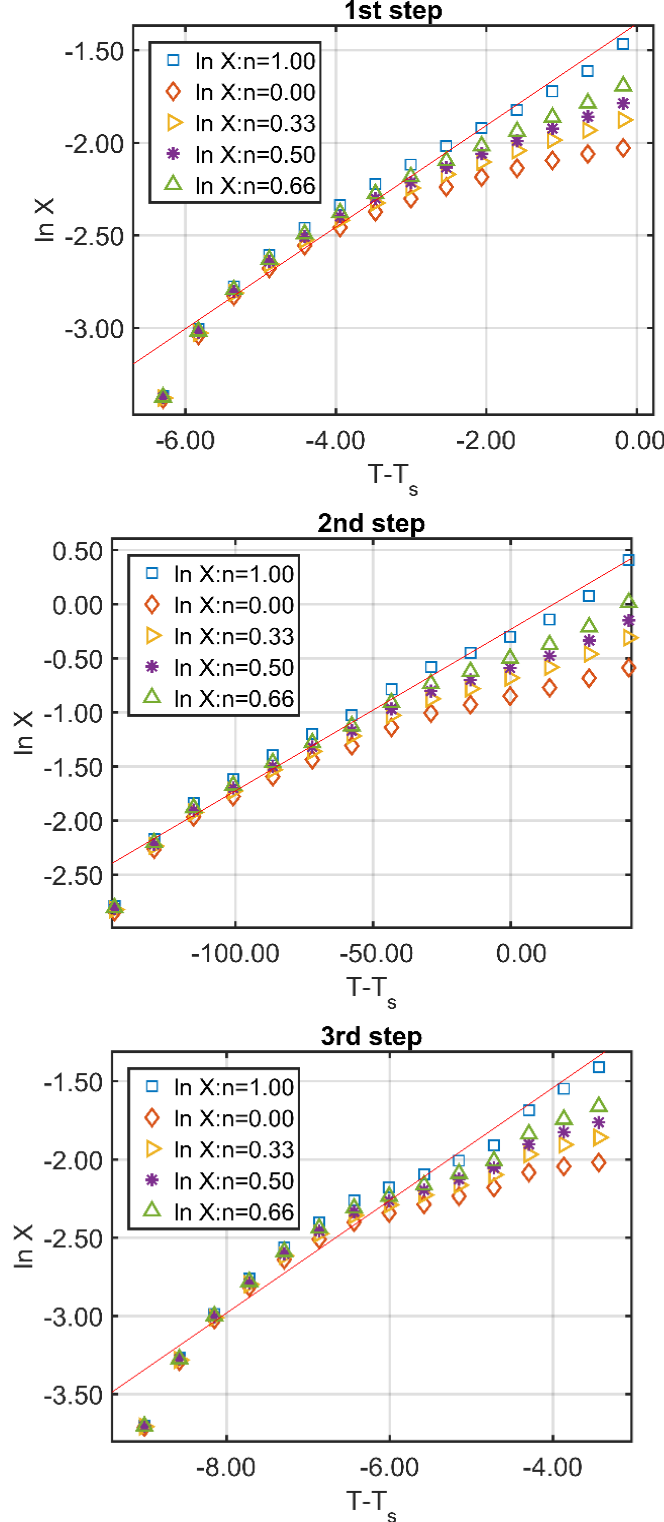

Figure 7: Horowitz- Metzger plots of $\left[\mathrm{Ni}(\mathrm{L})\left(\mathrm{H}_{2} \mathrm{O}\right)_{2}\right] \cdot 2 \mathrm{H}_{2} \mathrm{O}$ complex.

$$
\mathrm{d} \alpha / \mathrm{dt}=\mathrm{A} / \varnothing\left(\mathrm{e}^{(-\mathrm{E} / \mathrm{RT})}\right) f(\alpha)
$$

When the temperature varied by a constant and controlled heating rate, $\Phi=\mathrm{dT} / \mathrm{dt}$, the change in degree of conversion which is a function of temperature dependent also on time of heating. Therefore, Eq. (3) becomes:

$$
\mathrm{d} \alpha / \mathrm{dt}=\mathrm{A} / \varnothing\left(\mathrm{e}^{(-\mathrm{E} / \mathrm{RT})}\right) f(\alpha)
$$

By integrating Eq. (4):

$$
g(\alpha)=\int_{0}^{\alpha} \frac{\mathrm{d} \alpha}{f(\alpha)}=\frac{\mathrm{A}}{\varnothing} \int_{0}^{\mathrm{T}} \mathrm{e}^{-\mathrm{E} / \mathrm{RT}} \mathrm{dt}
$$

Where $g(\alpha)$ is the integrated form of the conversion dependence function? The right-hand side integral of Eq. (5) known as temperature integral; has no closed form solution and can be evaluated by CoatsRedfern (CR) method (Figure 6) [38] and the approximation method of Horowitz-Metzger (HM) (Figure 7) [39]. 
Citation: El-Reash YGA, Zaky R, Yaseen MA (2016) 2-(2-(2-Hydroxybenzyliden) Hydrazinyl)-2-Oxo-N-(Pyridine-2-Yl) Acetamide Complexes: Synthesis, Characterization and Biological Studies. Chem Sci J 7: 145. doi: 10.4172/2150-3494.1000145

Page 5 of 10

\begin{tabular}{|c|c|c|c|c|c|c|c|c|}
\hline \multirow{2}{*}{ Compound } & \multirow{2}{*}{ Step } & \multirow{2}{*}{$\begin{array}{c}\text { Mid } \\
\text { Temp. (K) }\end{array}$} & \multirow{2}{*}{ Method } & $E_{a}$ & A & $\Delta \mathbf{H}^{*}$ & $\Delta \mathbf{S}^{*}$ & $\Delta \mathbf{G}^{*}$ \\
\hline & & & & $\mathrm{KJ} / \mathrm{mol}$ & $\left(\mathbf{S}^{-1}\right)$ & $\mathrm{KJ} / \mathrm{mol}$ & $\mathrm{KJ} / \mathrm{mol} . \mathrm{K}$ & $\mathrm{KJ} / \mathrm{mol}$ \\
\hline \multirow{6}{*}[\mathrm{Ni}(\mathrm{L})(\mathrm{H}_{2}\mathrm{O})_{2}]{$\cdot 2 \mathrm{H}_{2} \mathrm{O}$} & \multirow{2}{*}{$1 \mathrm{st}$} & \multirow{2}{*}{334.08} & $\mathrm{HM}$ & 203.82 & $1.09 \times 10^{30}$ & 201.04 & 0.32915 & 91.08 \\
\hline & & & $\mathrm{CR}$ & 200.87 & $3.85 \times 10^{29}$ & 198.09 & 0.32053 & 91.01 \\
\hline & \multirow{2}{*}{ 2nd } & \multirow{2}{*}{457.82} & $\mathrm{HM}$ & 26.02 & 1.43 & 22.21 & -0.24548 & 134.60 \\
\hline & & & CR & 17.82 & $2.18 \times 10^{-01}$ & 14.01 & -0.26112 & 133.56 \\
\hline & \multirow{2}{*}{$3 r d$} & \multirow{2}{*}{599.12} & $\mathrm{HM}$ & 859.55 & $2.49 \times 10^{73}$ & 854.57 & 1.15437 & 162.96 \\
\hline & & & $\mathrm{CR}$ & 848.81 & $2.91 \times 10^{72}$ & 843.83 & 1.13652 & 162.92 \\
\hline
\end{tabular}

Table 2: Kinetic Parameters evaluated by Horowitz-Metzger and Coats-Redfern equations for $\mathrm{Ni}(\mathrm{II})$ and $\mathrm{Cu}(\mathrm{II})$ complexes of $\mathrm{H}_{2} \mathrm{~L}$.

(a)

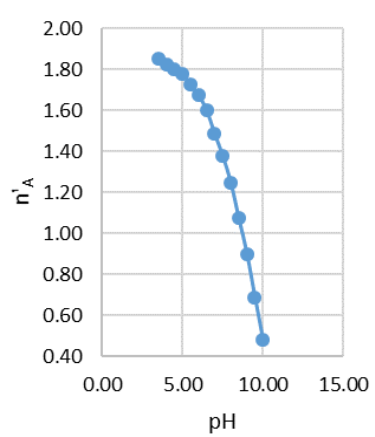

(c)

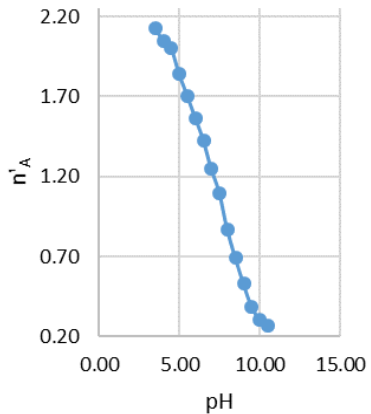

Figure 8: Proton-ligand formation curve of $\mathrm{H}_{2} \mathrm{~L}$ at (a) $298^{\circ} \mathrm{K}$ (b) $308^{\circ} \mathrm{K}$ (c) $318^{\circ} \mathrm{K}$.

\begin{tabular}{|c|c|c|c|c|c|c|}
\hline \multirow{2}{*}{ Ligand } & \multicolumn{6}{|c|}{ Association constants } \\
\cline { 2 - 7 } & \multicolumn{2}{|c|}{$298^{\circ} \mathrm{K}$} & \multicolumn{2}{c|}{$308^{\circ} \mathrm{K}$} & \multicolumn{2}{c|}{$318^{\circ} \mathrm{K}$} \\
\cline { 2 - 7 } & $\mathrm{pK}_{1}$ & $\mathrm{pK}_{2}$ & $\mathrm{pK}_{1}$ & $\mathrm{pK}_{2}$ & $\mathrm{pK}_{1}$ & $\mathrm{pK}_{2}$ \\
\hline \multirow{2}{*}{$\mathbf{H}_{\mathbf{2}} \mathrm{L}$} & 9.95 & 6.94 & 9.20 & 6.76 & 9.11 & 6.24 \\
\hline
\end{tabular}

Table 3: The association constants of $\mathrm{H}_{2} \mathrm{~L}$ in $50 \%$ (v/v) DMSO- water, $0.05 \mathrm{M} \mathrm{KCl}$ and at different temperature.

From the obtained results:

i) All kinetic parameters (E, $A, \Delta H^{*}, \Delta S^{*}$ and $\left.\Delta G^{*}\right)$ for all prepared solid complex were calculated by CR and HM method (Table 2). Both methods gave comparable values.

ii) For all complexes; decomposition stages fitted better when $(\mathrm{n}=1)$ suggesting a 1st-order decomposition process. Other $\mathrm{n}$ values (eq. 3 and 4 ) did not show better correlations.

iii) The value of $\Delta G$ increases for complexes because while going from one decomposition step to another; the rate of $\mathrm{H}_{2} \mathrm{~L}$ removal will be lower $[40,41]$. This can be due to, the rigidity of remaining complex after the explosion of one or more $\mathrm{H}_{2} \mathrm{~L}$ molecules. iv) The values of the entropy $\left(\Delta S^{*}\right)$ for the decomposition steps of complexes show that the activated fragments have more ordered (negative values) or disordered (positive values) structure than the undecomposed complexes and/or the decomposition reactions are slow [38].

v) The positive value of $\Delta \mathrm{H}^{\star}$ means the endothermic nature of the decomposition processes.

Generally, the values of stability constants decrease with increasing the number of $\mathrm{H}_{2} \mathrm{~L}$ atoms attached to the metal ion $[42,43]$. Therefore, an opposite effect may occur during the decomposition process. Hence, the rate of removal of the remaining $\mathrm{H}_{2} \mathrm{~L}$ will be lower than that of the rate before the explosion of $\mathrm{H}_{2} \mathrm{~L}$.

\section{Potentiometric studies}

Proton-ligand system: Irving-Rossotti equation used to calculate the average number of protons associated with the ligand $\left(\mathrm{n}_{\mathrm{A}}\right)$ at different $\mathrm{pH}$-values.

$$
\overline{\mathrm{n}}_{\mathrm{A}}=\mathrm{Y}+\frac{\left(\mathrm{V}_{1}-\mathrm{V}_{2}\right)\left(\mathrm{N}^{0}+\mathrm{E}^{0}\right)}{\left(\mathrm{V}_{0}+\mathrm{V}_{1}\right) \mathrm{TC}_{\mathrm{L}}^{0}}
$$

Where $\mathrm{Y}$ is the number of ionizable protons in the ligand atom, $\mathrm{C}_{\mathrm{L}}$ is the initial ligand concentration, $\mathrm{V}_{1}$ and $\mathrm{V}_{2}$ are the volumes of $\mathrm{NaOH}$ needed to reach the same $\mathrm{pH}$ value in titration against the free acid and in the ligand mixtures, respectively. $\mathrm{V}$ is the initial volume of the mixture (25 ml), and $\mathrm{N}^{\circ}$ and $\mathrm{E}^{\circ}$ are the concentration of the alkali and the free acid, respectively. The formation curves plotted between $\mathrm{n}_{\mathrm{A}}$ and $\mathrm{pH}$ for the proton-ligand systems (Figure 8). It is found that $n_{A}$ values extend between 0 and 2 indicating that the ligand has two dissociable hydrogen ions of $\mathrm{NH}_{1}$ and $\mathrm{NH}_{2}$ respectively. Also, the dissociation constants, $\mathrm{pK}_{1}$ and $\mathrm{pK}_{2}$ can be obtained directly from these curves by interpolation at $\mathrm{n}_{\mathrm{A}}=0.5$ and 1.5 , respectively. The values recorded in Table 3 . Inspection of the table reveals that $\mathrm{pK}_{1}>\mathrm{pK}_{2}$ at the same temperature. In addition, the $\mathrm{pK}$ values decrease with increasing temperature indicating that acidity increases with increasing temperature.

Metal-ligand system: In the present work, metal ions under study were titrated against $\mathrm{NaOH}$ solution. $\mathrm{n}$ and $\mathrm{pL}$ values were evaluated by Irving and Rossotti.

$$
\overline{\mathrm{n}}=\frac{\left(\mathrm{V}_{3}-\mathrm{V}_{2}\right)\left(\mathrm{N}^{0}+\mathrm{E}^{0}\right)}{\left(\mathrm{V}_{0}+\mathrm{V}_{2}\right) \overline{\mathrm{n}}_{\mathrm{A}} \mathrm{TC}_{\mathrm{M}}^{0}}
$$

Where $\mathrm{V}_{3}$ is the volume of $\mathrm{NaOH}$ needed to adjust the $\mathrm{pH}$ in the complex solution, $C^{o}{ }_{M}$ is the initial metal ion concentration.

Furthermore, pL values can be determined for dibasic acid using the following equation:

$$
p L=\log \frac{1+\mathrm{K}_{1}\left[\mathrm{H}^{+}\right]+\mathrm{K}_{1} \mathrm{~K}_{2}\left[\mathrm{H}^{+}\right]^{2}}{\mathrm{~T}_{\mathrm{L}}-\overline{\mathrm{n}} \mathrm{T}_{\mathrm{M}}} \times \frac{\mathrm{V}_{3}+\mathrm{V}_{0}}{\mathrm{~V}_{0}}
$$

The formation of both $\mathrm{ML}$ and $\mathrm{ML}_{2}$ type of complexes was 
Citation: El-Reash YGA, Zaky R, Yaseen MA (2016) 2-(2-(2-Hydroxybenzyliden) Hydrazinyl)-2-Oxo-N-(Pyridine-2-Yl) Acetamide Complexes: Synthesis, Characterization and Biological Studies. Chem Sci J 7: 145. doi: 10.4172/2150-3494.1000145

confirmed by the value of $(\mathrm{n})$ that was found to be $\sim 2$. The calculated stability constant values summarized in Table 4 .

Distribution curves: The different protonated forms as $\mathrm{H}_{2} \mathrm{~L}, \mathrm{HL}$ and $\mathrm{L}^{2-}$ were detected during the titration processes. The distribution curves of $\mathrm{H}_{2} \mathrm{~L}$ displayed in Figure 9 at $298^{\circ} \mathrm{K}$ as a symbolic example. It is obvious that all protonated species have a wide protonation range between $\mathrm{pH} 5-13$. While increasing the $\mathrm{pH}$ results in loosing protons of ligands and conversion to the other forms. The percentage of $\mathrm{H}_{2} \mathrm{~L}$, $\mathrm{HL}^{-}$and $\mathrm{L}^{2-}$ forms are above $95 \%$ and the free ligand $(\mathrm{L})$ formed at $\mathrm{pH}$ 9.8 and reached its maximum at $\mathrm{pH}$ 13.2.

The formed $\mathrm{Co}(\mathrm{II})$ complexes formulated as $\left(\mathrm{ML}_{2}, \mathrm{ML}\right)$ were $\mathrm{pH}$ dependent. The distribution curves resulted from the calculations

\begin{tabular}{|c|c|c|c|c|c|c|}
\hline \multirow{2}{*}{ Cation } & \multicolumn{6}{|c|}{ Stability constants } \\
\cline { 2 - 7 } & \multicolumn{2}{|c|}{$298^{\circ} \mathrm{K}$} & \multicolumn{2}{|c|}{$308^{\circ} \mathrm{K}$} & \multicolumn{2}{c|}{$318^{\circ} \mathrm{K}$} \\
\cline { 2 - 7 } & $\operatorname{logK}_{1}$ & $\operatorname{logK}_{2}$ & $\operatorname{logK}_{1}$ & $\log K_{2}$ & $\operatorname{logK}_{1}$ & $\operatorname{logK}_{2}$ \\
\hline \multirow{2}{*}{ Co(II) } & 6.35 & - & 6.27 & 4.29 & 6.23 & 3.87 \\
\hline
\end{tabular}

Table 4: The Stability Constants of Metal lons- $\mathrm{H}_{2} \mathrm{~L}$ Complexes in $50 \%$ (v/v) DMSOwater, $0.05 \mathrm{M} \mathrm{KCl}$ and at different temperature.

(a)

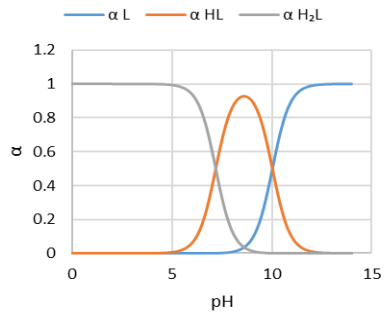

(b)

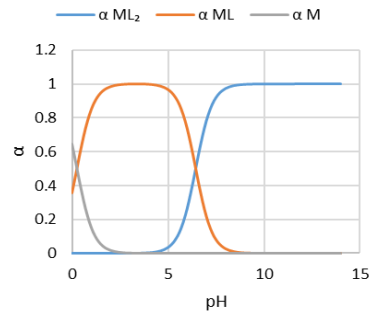

$\mathrm{pH}$

Figure 9: distribution curve of (a) $\mathrm{H}_{2} \mathrm{~L}$ (b) $\mathrm{Co}(\mathrm{II})-\mathrm{H}_{2} \mathrm{~L}$.

\begin{tabular}{|c|c|c|c|c|c|}
\hline \multirow[t]{2}{*}{ ligand } & \multicolumn{3}{|c|}{$\begin{array}{l}\text { Free energy changes }(\Delta \mathbf{G}) \mathrm{KJ} \\
\mathrm{mol}^{-1}\end{array}$} & \multirow{2}{*}{$\begin{array}{c}\text { Enthalpy } \\
\text { changes }(\Delta \mathrm{H}) \\
\mathrm{KJ} \mathrm{mol}^{-1}\end{array}$} & \multirow{2}{*}{$\begin{array}{c}\text { entropy changes } \\
(\Delta \mathbf{S}) \\
\mathrm{K} \mathrm{J} \mathrm{mol}^{-1}\end{array}$} \\
\hline & $298^{\circ} \mathrm{K}$ & $308^{\circ} \mathrm{K}$ & $318^{\circ} \mathrm{K}$ & & \\
\hline
\end{tabular}

\begin{tabular}{|l|l|l|l|l|l|l|l|l|l|l|}
$\mathbf{H}_{2} \mathbf{L}$ & 98.52 & 87.02 & 99.23 & 87.81 & 99.94 & 88.59 & 77.37 & 63.49 & $-7.10 \times 10^{-2}$ & $-7.90 \times 10^{-2}$ \\
\hline
\end{tabular}

Table 5: Thermodynamic parameters of $\mathrm{H}_{2} \mathrm{~L}$ in $50 \%(\mathrm{v} / \mathrm{v})$ DMSO-water, $0.05 \mathrm{M} \mathrm{KCl}$ and at different temperature.

\begin{tabular}{|c|c|c|c|c|c|c|c|c|}
\hline \multirow{2}{*}{ Cation } & \multicolumn{5}{|c|}{$\begin{array}{l}\text { Free energy changes }(\Delta \mathbf{G}) \mathrm{KJ} \\
\text { mol}^{-1}\end{array}$} & \multirow{2}{*}{\multicolumn{2}{|c|}{$\begin{array}{c}\text { Enthalpy } \\
\text { changes }(\Delta \mathrm{H}) \\
\mathrm{KJ} \mathrm{mol}^{-1}\end{array}$}} & \multirow{2}{*}{$\begin{array}{c}\text { Entropy } \\
\text { changes }(\Delta \mathbf{S}) \mathbf{K} \\
\mathrm{J} \mathrm{mol}^{-1}\end{array}$} \\
\hline & & & $308^{\circ} \mathrm{r}$ & & $318^{\circ} \mathrm{K}$ & & & \\
\hline $\mathrm{Co}(\mathrm{II})$ & -12.58 & & -13.40 & - & -14.21 & 11.83 & - & $8.19 \times 10^{-2}$ \\
\hline
\end{tabular}

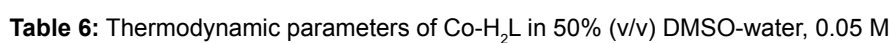
$\mathrm{KCl}$ and at different temperature.

(a)

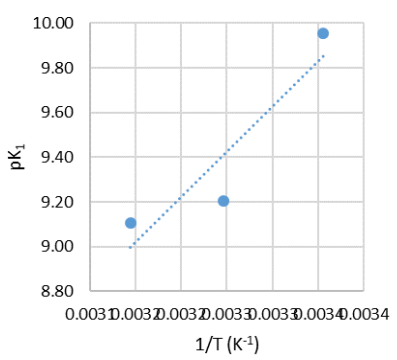

Figure 10: Temperatures dependence of pK values of (a) $\mathrm{pK}_{1}$ (b) $\mathrm{pK}_{2}$ of $\mathrm{H}_{2} \mathrm{~L}$ at ionic strength $0.05 \mathrm{M} \mathrm{KCl}$.

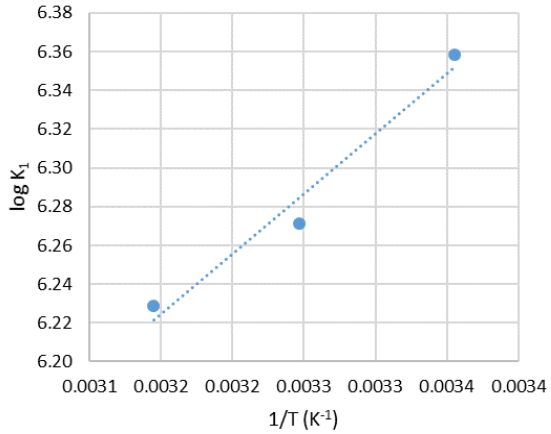

Figure 11: The Relation between $\log \mathrm{K}_{1}$ Against 1/T of Co(II)- $\mathrm{H}_{2} \mathrm{~L}$.

shown in Figure 9 at $298^{\circ} \mathrm{K}$. Co(II) complexes are formed after $\mathrm{pH} 4.9$, while the intermediate complexes are formed between $\mathrm{pH}$ 1.3-5.0.

The thermodynamic parameters: The corresponding thermodynamic parameters (standard free energy change, $\Delta G^{\circ}$ and the standard entropy change, $\Delta S^{\circ}$ ) for dissociation and metal complex formation were calculated via the following equations:

$$
\begin{aligned}
& \Delta \mathrm{G}^{\circ}=-2.303 \mathrm{RT} \log \mathrm{K}_{\mathrm{H}}=2.303 \mathrm{RT}_{\mathrm{pK}} \mathrm{H}_{\mathrm{H}} \\
& \Delta \mathrm{G}^{\circ}=\Delta \mathrm{H}^{\circ}-\mathrm{T} \Delta \mathrm{S}^{\circ}
\end{aligned}
$$

The calculated thermodynamic functions are recorded in Tables 5 and 6 and Figures 10 and 11 .

Checking these, values show that:

a) For proton-ligand system:

i) The positive values of $\Delta G^{\circ}$ indicate a non-spontaneous dissociation processes.

ii) The negative values of $\Delta S^{\circ}$ are due to increasing the order because of solvation process. This may be explained as the number of bound of solvent molecules accompanying with the undissociated ligand being less than those accompanying the dissociated form.

iii) The positive values of $\Delta \mathrm{H}^{\circ}$ indicate the endothermic nature of the dissociation of ligand in aqueous solution. The process accompanied by heat absorption indicating the favorability of the process at higher temperatures.

\section{b) For metal-ligand system:}

i) The negative values of $\Delta G^{\circ}$ indicate that the spontaneous nature of the chelation process.

ii) The positive values of $\Delta S^{\circ}$ are owing to the decreasing the order due to solvation process.

iii) The positive values of $\Delta \mathrm{H}^{\circ}$ indicate that the chelation process is endothermic and accompanied by consuming of heat and the chelation process is favorable at higher temperatures.

\section{Molecular modelling}

The molecular structures of $\mathrm{H}_{2} \mathrm{~L}$ and its complexes shown in Structures 1-3 an insight to the data in Tables 7-13 reveals the following remarks:

i) The bond angles of the hydrazone moiety of $\mathrm{H}_{2} \mathrm{~L}$ changed slightly upon coordination; the largest change affects in $\mathrm{H}_{2} \mathrm{~L}$ are $\mathrm{O}(21)-\mathrm{C}(17)-\mathrm{C}(18), \mathrm{C}(18)-\mathrm{C}(12)-\mathrm{N}(11), \mathrm{C}(12)-\mathrm{N}(11)-\mathrm{N}(10), \mathrm{N}(11)-$ 
Citation: El-Reash YGA, Zaky R, Yaseen MA (2016) 2-(2-(2-Hydroxybenzyliden) Hydrazinyl)-2-Oxo-N-(Pyridine-2-Yl) Acetamide Complexes: Synthesis, Characterization and Biological Studies. Chem Sci J 7: 145. doi: 10.4172/2150-3494.1000145

Page 7 of 10

\begin{tabular}{|c|c|c|c|c|}
\hline Bond & Length(A) & Bond & Length(A) & Bond \\
\hline $\mathrm{C}(17)-\mathrm{O}(21)$ & 1.385 & $\mathrm{C}(17)-\mathrm{C}(18)$ & 1.422 & $\mathrm{C}(18)-\mathrm{C}(12)$ \\
\hline $\mathrm{N}(11)-\mathrm{C}(12)$ & 1.300 & $\mathrm{~N}(10)-\mathrm{N}(11)$ & 1.362 & $\mathrm{C}(9)-\mathrm{O}(14)$ \\
\hline $\mathrm{C}(9)-\mathrm{N}(10)$ & 1.375 & $\mathrm{C}(8)-\mathrm{O}(13)$ & 1.245 & $\mathrm{C}(8)-\mathrm{C}(9)$ \\
\hline $\mathrm{N}(7)-\mathrm{C}(8)$ & 1.365 & & \\
\hline
\end{tabular}

Table 7: Selected bond lengths $(\AA)$ of $\mathrm{H}_{2} \mathrm{~L}$ in using DFT-method from $\mathrm{DMOL}^{3}$ calculations.

\begin{tabular}{|c|c|c|c|c|}
\hline Angle & Degree $\left(^{\circ}\right)$ & Angle & Degree $\left(^{\circ}\right)$ & Degree $\left(^{\circ}\right)$ \\
\hline $\mathrm{C}(17)-\mathrm{C}(18) \mathrm{C}-(12)$ & 121.689 & $\mathrm{O}(21)-\mathrm{C}(17)-\mathrm{C}(18)$ & 124.341 & $\mathrm{C}(18)-\mathrm{C}(12)-\mathrm{N}(11)$ \\
\hline $\mathrm{C}(12)-\mathrm{N}(11)-\mathrm{N}(10)$ & 115.857 & $\mathrm{~N}(11)-\mathrm{N}(10)-\mathrm{C}(9)$ & 122.561 & $\mathrm{O}(14)-\mathrm{C}(9)-\mathrm{N}(10)$ \\
\hline $\mathrm{O}(14)-\mathrm{C}(9)-\mathrm{C}(8)$ & 123.274 & $\mathrm{~N}(10)-\mathrm{C}(9)-\mathrm{C}(8)$ & 109.661 & $\mathrm{O}(13)-\mathrm{C}(8)-\mathrm{C}(9)$ \\
\hline $\mathrm{O}(13)-\mathrm{C}(8)-\mathrm{N}(7)$ & 127.169 & $\mathrm{C}(9)-\mathrm{C}(8)-\mathrm{N}(7)$ & 110.876 & 127.066 \\
\hline
\end{tabular}

Table 8: Selected bond angles $\left(^{\circ}\right)$ of $\mathrm{H}_{2} \mathrm{~L}$ in using DFT-method from DMOL ${ }^{3}$ calculations.

\begin{tabular}{|c|c|c|c|c|}
\hline Bond & Length $(\boldsymbol{A})$ & Bond & Length $(\mathbf{A})$ & Bond \\
\hline $\mathrm{O}(21)-\mathrm{C}(14)$ & 1.402 & $\mathrm{O}(24)-\mathrm{Co}(22)$ & 2.37 & $\mathrm{O}(23)-\mathrm{Co}(22)$ \\
\hline $\mathrm{O}(21)-\mathrm{Co}(22)$ & 2.407 & $\mathrm{O}(20)-\mathrm{Co}(22)$ & 2.304 & $\mathrm{O}(19)-\mathrm{Co}(22)$ \\
\hline $\mathrm{C}(13)-\mathrm{C}(14)$ & 1.441 & $\mathrm{C}(12)-\mathrm{C}(13)$ & 1.439 & $\mathrm{~N}(11)-\mathrm{Co}(22)$ \\
\hline $\mathrm{N}(11)-\mathrm{C}(12)$ & 1.363 & $\mathrm{~N}(10)-\mathrm{N}(11)$ & 1.36 & $\mathrm{C}(9)-\mathrm{O}(20)$ \\
\hline $\mathrm{C}(9)-\mathrm{N}(10)$ & 1.419 & $\mathrm{C}(8)-\mathrm{O}(19)$ & 1.319 & $\mathrm{C}(8)-\mathrm{C}(9)$ \\
\hline $\mathrm{N}(7)-\mathrm{C}(8)$ & 1.335 & & & 1.324 \\
\hline
\end{tabular}

Table 9: Selected bond lengths $(\AA)$ of $\left[\mathrm{Co}(\mathrm{L})\left(\mathrm{H}_{2} \mathrm{O}\right)_{2}\right] \cdot 2 \mathrm{H}_{2} \mathrm{O}$ in using DFT-method from $\mathrm{DMOL}^{3}$ calculations.

\begin{tabular}{|c|c|c|c|c|}
\hline Angle & Degree $\left(^{\circ}\right)$ & Angle & Degree $\left(^{\circ}\right)$ & Angle \\
\hline $\mathrm{O}(24)-\mathrm{Co}(22)-\mathrm{O}(23)$ & 87.047 & $\mathrm{O}(24)-\mathrm{Co}(22)-\mathrm{O}(21)$ & 86.13 & $\mathrm{O}(24)-\mathrm{Co}(22)-\mathrm{O}(20)$ \\
\hline $\mathrm{O}(24)-\mathrm{Co}(22)-\mathrm{O}(19)$ & 164.27 & $\mathrm{O}(24)-\mathrm{Co}(22)-\mathrm{N}(11)$ & 93.498 & $\mathrm{O}(23)-\mathrm{Co}(22)-\mathrm{O}(21)$ \\
\hline $\mathrm{O}(23)-\mathrm{Co}(22)-\mathrm{O}(20)$ & 102.689 & $\mathrm{O}(23)-\mathrm{Co}(22)-\mathrm{O}(19)$ & 85.986 & $\mathrm{O}(23)-\mathrm{Co}(22)-\mathrm{N}(11)$ \\
\hline $\mathrm{O}(21)-\mathrm{Co}(22)-\mathrm{O}(20)$ & 152.47 & $\mathrm{O}(21)-\mathrm{Co}(22)-\mathrm{O}(19)$ & 109.269 & $\mathrm{O}(21)-\mathrm{Co}(22)-\mathrm{N}(11)$ \\
\hline $\mathrm{O}(20)-\mathrm{Co}(22)-\mathrm{O}(19)$ & 77.207 & $\mathrm{O}(20)-\mathrm{Co}(22)-\mathrm{N}(11)$ & 74.831 & $\mathrm{O}(19)-\mathrm{Co}(22)-\mathrm{N}(11)$ \\
\hline $\mathrm{C}(14)-\mathrm{O}(21)-\mathrm{Co}(22)$ & 120.74 & $\mathrm{Co}(22)-\mathrm{O}(20)-\mathrm{C}(9)$ & 85.952 & $\mathrm{Co}(22)-\mathrm{O}(19)-\mathrm{C}(8)$ \\
\hline $\mathrm{O}(21)-\mathrm{C}(14)-\mathrm{C}(13)$ & 118.651 & $\mathrm{C}(14)-\mathrm{C}(13)-\mathrm{C}(12)$ & 125.807 & $\mathrm{C}(13)-\mathrm{C}(12)-\mathrm{N}(11)$ \\
\hline $\mathrm{Co}(22)-\mathrm{N}(11)-\mathrm{C}(12)$ & 133.076 & $\mathrm{Co}(22)-\mathrm{N}(11)-\mathrm{N}(10)$ & 107.35 & $\mathrm{C}(12)-\mathrm{N}(11)-\mathrm{N}(10)$ \\
\hline $\mathrm{N}(11)-\mathrm{N}(10)-\mathrm{C}(9)$ & 109.723 & $\mathrm{O}(20)-\mathrm{C}(9)-\mathrm{N}(10)$ & 117.763 & $\mathrm{O}(20)-\mathrm{C}(9)-\mathrm{C}(8)$ \\
\hline $\mathrm{N}(10)-\mathrm{C}(9)-\mathrm{C}(8)$ & 114.546 & $\mathrm{O}(19)-\mathrm{C}(8)-\mathrm{C}(9)$ & 111.335 & $\mathrm{O}(19)-\mathrm{C}(8)-\mathrm{N}(7)$ \\
\hline $\mathrm{C}(9)-\mathrm{C}(8)-\mathrm{N}(7)$ & 120.987 & & 114.496 \\
\hline
\end{tabular}

Table 10: Selected bond angles $\left(^{\circ}\right)$ of $\left[\mathrm{Co}(\mathrm{L})\left(\mathrm{H}_{2} \mathrm{O}\right)_{2}\right] \cdot 2 \mathrm{H}_{2} \mathrm{O}$ in using DFT-method from $\mathrm{DMOL}^{3}$ calculations.

\begin{tabular}{|c|c|c|c|c|}
\hline Bond & Length $(\mathbf{A})$ & Bond & Length $(\mathbf{A})$ & Bond \\
\hline $\mathrm{C}(14)-\mathrm{O}(21)$ & 1.518 & $\mathrm{O}(24)-\mathrm{Ni}(22)$ & 2.125 & $\mathrm{O}(23)-\mathrm{Ni}(22)$ \\
\hline $\mathrm{O}(21)-\mathrm{Ni}(22)$ & 2.12 & $\mathrm{O}(20)-\mathrm{Ni}(22)$ & 2.127 & $\mathrm{O}(19)-\mathrm{Ni}(22)$ \\
\hline $\mathrm{C}(13)-\mathrm{C}(14)$ & 1.558 & $\mathrm{C}(12)-\mathrm{C}(13)$ & 1.548 & $\mathrm{~N}(11)-\mathrm{Ni}(22)$ \\
\hline $\mathrm{N}(11)-\mathrm{C}(12)$ & 1.505 & $\mathrm{~N}(10)-\mathrm{N}(11)$ & 1.463 & $\mathrm{C}(9)-\mathrm{O}(20)$ \\
\hline $\mathrm{C}(9)-\mathrm{N}(10)$ & 1.516 & $\mathrm{C}(8)-\mathrm{O}(19)$ & 1.515 & $\mathrm{C}(8)-\mathrm{C}(9)$ \\
\hline $\mathrm{N}(7)-\mathrm{C}(8)$ & 1.511 & & & 1.531 \\
\hline
\end{tabular}

Table 11: Selected bond lengths $(\AA)$ of $\left[\mathrm{Ni}(\mathrm{L})\left(\mathrm{H}_{2} \mathrm{O}\right)_{2}\right] \cdot 2 \mathrm{H}_{2} \mathrm{O}$ in using DFT-method from DMOL ${ }^{3}$ calculations.

\begin{tabular}{|c|c|c|c|c|c|}
\hline Angle & Degree $\left(^{\circ}\right)$ & Angle & Degree $\left(^{\circ}\right)$ & Angle & Degree $\left(^{\circ}\right)$ \\
\hline $\mathrm{O}(24)-\mathrm{Ni}(22)-\mathrm{O}(23)$ & 90.077 & $\mathrm{O}(24)-\mathrm{Ni}(22)-\mathrm{O}(21)$ & 90.093 & $\mathrm{O}(24)-\mathrm{Ni}(22)-\mathrm{O}(20)$ & 177.723 \\
\hline $\mathrm{O}(24)-\mathrm{Ni}(22)-\mathrm{O}(19)$ & 90.57 & $\mathrm{O}(24)-\mathrm{Ni}(22)-\mathrm{N}(11)$ & 92.124 & $\mathrm{O}(23)-\mathrm{Ni}(22)-\mathrm{O}(21)$ & 90.329 \\
\hline $\mathrm{O}(23)-\mathrm{Ni}(22)-\mathrm{O}(20)$ & 91.861 & $\mathrm{O}(23)-\mathrm{Ni}(22)-\mathrm{O}(19)$ & 89.951 & $\mathrm{O}(23)-\mathrm{Ni}(22)-\mathrm{N}(11)$ & 177.593 \\
\hline $\mathrm{O}(21)-\mathrm{Ni}(22)-\mathrm{O}(20)$ & 91.09 & $\mathrm{O}(21)-\mathrm{Ni}(22)-\mathrm{O}(19)$ & 179.279 & $\mathrm{O}(21)-\mathrm{Ni}(22)-\mathrm{N}(11)$ & 88.693 \\
\hline $\mathrm{O}(20)-\mathrm{Ni}(22)-\mathrm{O}(19)$ & 88.237 & $\mathrm{O}(20)-\mathrm{Ni}(22)-\mathrm{N}(11)$ & 85.959 & $\mathrm{O}(19)-\mathrm{Ni}(22)-\mathrm{N}(11)$ & 91.001 \\
\hline $\mathrm{C}(14)-\mathrm{O}(21)-\mathrm{Ni}(22)$ & 115.507 & $\mathrm{Ni}(22)-\mathrm{O}(20)-\mathrm{C}(9)$ & 87.219 & $\mathrm{Ni}(22)-\mathrm{O}(19)-\mathrm{C}(8)$ & 98.182 \\
\hline $\mathrm{O}(21)-\mathrm{C}(14)-\mathrm{C}(13)$ & 122.718 & $\mathrm{C}(14)-\mathrm{C}(13)-\mathrm{C}(12)$ & 122.851 & $\mathrm{C}(13)-\mathrm{C}(12)-\mathrm{N}(11)$ & 121.286 \\
\hline $\mathrm{Ni}(22)-\mathrm{N}(11)-\mathrm{C}(12)$ & 123.787 & $\mathrm{Ni}(22)-\mathrm{N}(11)-\mathrm{N}(10)$ & 107.168 & $\mathrm{C}(12)-\mathrm{N}(11)-\mathrm{N}(10)$ & 124.018 \\
\hline $\mathrm{N}(11)-\mathrm{N}(10)-\mathrm{C}(9)$ & 105.804 & $\mathrm{O}(20)-\mathrm{C}(9)-\mathrm{N}(10)$ & 116.187 & $\mathrm{O}(20)-\mathrm{C}(9)-\mathrm{C}(8)$ & 111.086 \\
\hline $\mathrm{N}(10)-\mathrm{C}(9)-\mathrm{C}(8)$ & 111.993 & $\mathrm{O}(19)-\mathrm{C}(8)-\mathrm{C}(9)$ & 114.38 & $\mathrm{O}(19)-\mathrm{C}(8)-\mathrm{N}(7)$ & 123.676 \\
\hline $\mathrm{C}(9)-\mathrm{C}(8)-\mathrm{N}(7)$ & 121.756 & & & \\
\hline
\end{tabular}

Table 12: Selected bond angles $\left(^{\circ}\right)$ of $\left[\mathrm{Ni}(\mathrm{L})\left(\mathrm{H}_{2} \mathrm{O}\right)_{2}\right] \cdot 2 \mathrm{H}_{2} \mathrm{O}$ in using DFT-method from $\mathrm{DMOL}^{3}$ calculations. 
Citation: El-Reash YGA, Zaky R, Yaseen MA (2016) 2-(2-(2-Hydroxybenzyliden) Hydrazinyl)-2-Oxo-N-(Pyridine-2-Yl) Acetamide Complexes: Synthesis, Characterization and Biological Studies. Chem Sci J 7: 145. doi: 10.4172/2150-3494.1000145

Page 8 of 10

\begin{tabular}{|c|c|c|c|c|c|c|c|c|c|}
\hline Compound & $E_{\mathrm{H}}(\mathrm{eV})$ & $E_{L}(\mathrm{eV})$ & $\left(E_{\mathrm{H}}-E_{\mathrm{L}}\right)(\mathrm{eV})$ & $x(\mathrm{eV})$ & $\mu(e V)$ & $\eta(\mathrm{eV})$ & $S\left(\mathrm{eV}^{-1}\right)$ & $\omega(\mathrm{eV})$ & $6(\mathrm{eV})$ \\
\hline $\mathrm{H}_{2} \mathrm{~L}$ & -5.356 & -2.791 & -2.565 & 4.074 & -4.074 & 1.283 & 0.641 & 6.469 & 0.780 \\
\hline$\left[\mathrm{Co}(\mathrm{L})\left(\mathrm{H}_{2} \mathrm{O}\right)_{2}\right] \cdot 2 \mathrm{H}_{2} \mathrm{O}$ & -3.980 & -2.492 & -1.488 & 3.236 & -3.236 & 0.744 & 0.372 & 7.037 & 1.344 \\
\hline$\left[\mathrm{Ni}(\mathrm{L})\left(\mathrm{H}_{2} \mathrm{O}\right)_{2}\right] \cdot 2 \mathrm{H}_{2} \mathrm{O}$ & -4.296 & -2.210 & -2.086 & 3.253 & -3.253 & 1.043 & 0.522 & 5.073 & 0.959 \\
\hline
\end{tabular}

Table 13: Calculated $E_{\text {номо }}, E_{L u м 0}$, energy band gap $\left(E_{H}-E_{L}\right)$, chemical potential $(\mu)$, electronegativity $(X)$, global hardness $(\eta)$, global softness $(S)$ and global electrophilicity index $(\omega)$ for $\mathrm{H}_{2} \mathrm{~L}$ and its complexes.

\begin{tabular}{|c|c|c|c|c|c|c|}
\hline Compound & E. coli & P. aeuroginosa & S. aureus & B. subtilis & C. albicans & A. flavus \\
\hline $\mathrm{H}_{2} \mathrm{~L}$ & 187.5 & 125 & 93.7 & 62.5 & 7.8 & 5.8 \\
\hline Co (II)-complex & NA & NA & 500 & 375 & 125 & 375 \\
\hline $\mathrm{Ni}$ (II)-complex & 250 & 187.5 & 125 & 125 & 11.7 & 7.8 \\
\hline Ampicillin & 125 & 187.5 & 187.5 & 93.7 & ---- & ---- \\
\hline Colitrimazole & --- & ---- & ---- & ---- & 5.8 & 3.9 \\
\hline
\end{tabular}

Table 14: Antimicrobial and Antimycotic Activities in terms of MIC $(\mu \mathrm{g} / \mathrm{mL})$ of $\mathrm{H}_{2} \mathrm{~L}$ and its complexes.

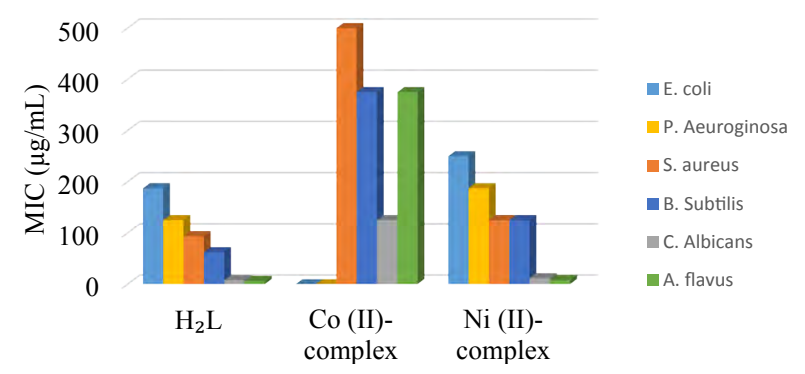

Figure 12: Biological Activities in terms of MIC $(\mu \mathrm{g} / \mathrm{mL})$ of $\mathrm{H}_{2} \mathrm{~L}$ and its complexes.

$\mathrm{N}(10)-\mathrm{C}(9), \quad \mathrm{O}(14)-\mathrm{C}(9)-\mathrm{N}(10), \quad \mathrm{O}(14)-\mathrm{C}(9)-\mathrm{C}(8), \quad \mathrm{O}(13)-\mathrm{C}(8)-\mathrm{N}(7)$ and $\mathrm{C}(9)-\mathrm{C}(8)-\mathrm{N}(7)$ angles. The bond angles in ligand are reduced or increased on complex formation because of bonding [44].

ii) The bond angles in metal complexes are quite near to an octahedral geometry predicting $\mathrm{d}^{2} \mathrm{sp}^{3}$ or $\mathrm{sp}^{3} \mathrm{~d}^{2}$ hybridization in all complexes [38].

iii) All the active groups in taking part in coordination have bonds longer than that already exist in the ligand moiety like $(\mathrm{C}-\mathrm{O})_{\text {enol }}(\mathrm{C}-\mathrm{O})$ phenolic, $\mathrm{C}=\mathrm{N}_{\text {azomethine }}$. This is referred to the formation of the $\mathrm{M}-\mathrm{N}$ bond which makes the $\mathrm{C}-\mathrm{N}$ bond weaker because of coordination via $\mathrm{N}$ atom of $(\mathrm{C}=\mathrm{N})$ [45].

iv) The bond lengths of $\mathrm{C}(9)-\mathrm{N}(10)$ and $\mathrm{C}(8)-\mathrm{N}(7)$ become slightly longer in complexes as the coordination takes place via $\mathrm{N}$ atoms of $-\mathrm{C}=\mathrm{N}-\mathrm{C}=\mathrm{N}$ - group that is formed on deprotonation of $\mathrm{OH}$ group in all complexes [44].

v) The bond distance of $(\mathrm{CO})_{\text {enolic }}$ that participate in coordination becomes longer due to the formation of the $\mathrm{M}-\mathrm{O}$ bond which makes the $\mathrm{C}-\mathrm{O}$ bond weaker $[46]$ while the phenolic $(\mathrm{C}-\mathrm{O})$ that participates in complexes will become longer on coordination.

vi) The bond angles of ligand moiety containing atoms of coordination will be changed in all complexes due to the formation of the N-M-O chelate ring [47].

vii) The arrangement of complexes based on $\mathrm{M}-\mathrm{O}$ and $\mathrm{M}-\mathrm{N}$ bond lengths indicates that; the $\mathrm{M}-\mathrm{N}$ and $\mathrm{M}-\mathrm{O}$ in $\mathrm{CO}(\mathrm{II})$ complex have greater strength than in $\mathrm{Ni}$ (II) complex.

viii) The low HOMO energy values indicate the weak electron donating ability of molecules. LUMO energy indicate the ability of molecules to receive electrons [44].

ix) The overlap happens between both HOMO and LUMO is an important factor in all reactions. This can be indicated from the large values of molecular orbital coefficients. So, the orbitals that have the highest molecular orbital coefficients in the ligand can be considered as the sites of coordination. In addition; the energy gap $\left(E_{\text {номо }}-E_{\mathrm{LUMO}}\right)$ is a significant stability index that supports the characterization of both kinetic stability and chemical reactivity for the studied molecules [48]. Where molecules with smaller gap are more polarized and known as soft molecule that are more reactive than hard ones because they offer electrons easily to the acceptor. In case of ligand $\left(\mathrm{H}_{2} \mathrm{~L}\right)$; the energy gap is small also due to the groups that enter conjugation. This indicates that charge transfer easily, which influences the biological activity of the molecule [49].

x) DFT method illustrates both the chemical reactivity and site selectivity for all molecular systems. The energies of frontier molecular orbitals $\left(E_{\mathrm{HOMO}}, E_{\mathrm{LUMO}}\right)$, band gap describes the ultimate charge transfer happens within molecules, chemical potential $(\mu)$, electronegativity $(\chi)$, global softness $(S)$ global hardness $(\eta)$ and global electrophilicity index $(\omega)[50,51]$ are listed in, the inverse value of the global hardness is designed as the softness $\sigma$ as follows:

$$
\sigma=1 / \eta
$$

\section{Biological activity}

Minimum Inhibitory Concentration (MIC): Ligand and their complexes were evaluated for their antibacterial activity against Staphylococcus aureus (S. aureus) and Bacillus subtilis (B. subtilis) as an example of Gram-positive bacteria, Escherichia coli (E. coli) and Pseudomonas aeuroginosa ( $P$. aeuroginosa) as examples of Gramnegative bacteria and against a pathogenic Candida albicans ( $C$. albicans) and Aspergillus flavus (A. flavus) fungal strain. Antimicrobial and Antimycotic Activities in terms of MIC $(\mu \mathrm{g} / \mathrm{mL})$ in Table 14 . The fungicide Colitrimazole and the bactericide Ampicillin were used as references to compare the potency of the tested compounds under the same conditions (Figure 12).

$\mathrm{H}_{2} \mathrm{~L}$ is the most potent compared with reference compounds against all bacterial and fungal stain. On the other hand, Co(II) complex shows no activity against $E$. Coli. While, it has lowest activity towards P. Aeuroginosa, S. aureus, B. Subtilis, C. Albicans and A. flavus with MIC 500, 375, 125, $375 \mu \mathrm{g} / \mathrm{ml}$, respectively. Ni(II) complex exhibited moderate activity against all bacterial and fungal stain.

The prepared compounds can be arranged according to its activities towards E. coli, C. albicans and A. flavus as follows:

DNA-binding affinity assay: It was noticed that; methyl green binds in a reversible manner with polymerized DNA [25], and prepared 
Citation: El-Reash YGA, Zaky R, Yaseen MA (2016) 2-(2-(2-Hydroxybenzyliden) Hydrazinyl)-2-Oxo-N-(Pyridine-2-Yl) Acetamide Complexes: Synthesis, Characterization and Biological Studies. Chem Sci J 7: 145. doi: 10.4172/2150-3494.1000145

\begin{tabular}{|c|c|}
\hline Compound & (IC $\left._{50}, \boldsymbol{\mu g} / \mathbf{m I}\right)$ \\
\hline $\mathrm{H}_{2} \mathrm{~L}$ & $27.8 \pm 1.7$ \\
\hline $\mathrm{Co}(\mathrm{II})$-complex & $69.1 \pm 3.8$ \\
\hline $\mathrm{Ni}(\mathrm{II})$-complex & $31.6 \pm 2.1$ \\
\hline
\end{tabular}

Table 15: DNA/methyl green $\mathrm{IC}_{50} \mu \mathrm{g} / \mathrm{ml}$ of $\mathrm{H}_{2} \mathrm{~L}$ and its metal complexes.

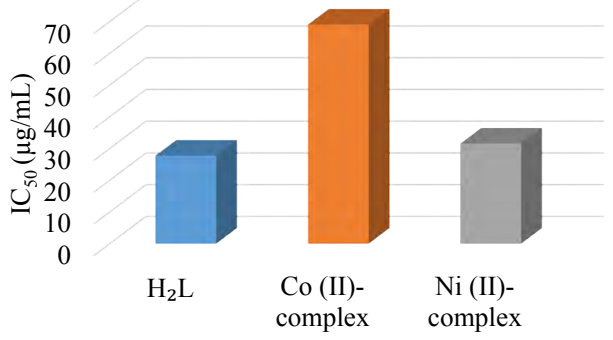

Figure 13: DNA/methyl green $\mathrm{IC}_{50} \mu \mathrm{g} / \mathrm{ml}$ of $\mathrm{H}_{2} \mathrm{~L}$ and its metal complexes.

complexes are stable in neutral pH medium, though free methyl green declines. In this study, buffer used for displacement reactions and after incubation for 24 hours, complete loss of methyl green absorbance was noticed. The dislodging of methyl green from DNA by studied compounds and the ability to bind to DNA was measured colorimetric. Where; the displacement was detected by the decrease in absorbance at $630 \mathrm{~nm}$ [52].

The prepared compounds were exhibited high affinity to DNA as shown in Table 15 and represented graphically in Figure 13, which was confirmed by keeping the DNA-complex at the origin or by migrating for short distances. The most active compounds were, $\mathrm{H}_{2} \mathrm{~L}$ and $\mathrm{Ni}$ (II)complex with $\mathrm{IC}_{50} 27.8 \pm 1.7$ and $31.6 \pm 2.1 \mu \mathrm{g} / \mathrm{ml}$, respectively. The obtained results agree with the antimicrobial and antifungal screening data. This suggests that; binding with DNA may be contributed to the biological activity of these compounds against bacterial and fungal infections.

$\mathrm{IC}_{50}$ values (mean $\pm \mathrm{SD}, \mathrm{n}=3-5$ separate determinations), exemplify the concentrations needed for a $50 \%$ decrease in the initial absorbance the DNA/methyl green solution.

\section{Conclusion}

The hydrazone derived from the condensation 2-hydrazinyl2-oxo-N-(pyridin-2-yl) acetamide to 2-hydroxybenzaldehyde (salicylaldehyde) and its $\mathrm{Co}(\mathrm{II})$ and $\mathrm{Ni}(\mathrm{II})$ complexes were produced. IR spectra suggest that the $\mathrm{H}_{2} \mathrm{~L}$ coordinates as binegative tetradentate via $(\mathrm{C}=\mathrm{N})_{\mathrm{az}}$, both $(\mathrm{C}-\mathrm{O})$ enolized with deprotonation and $(\mathrm{OH})_{\text {phenolic }}$. The proposed geometries of isolated complexes were proved using DFT. The pH-metrically at different temperatures in 50\% DMSO-water mixture was applied to estimate the dissociation constant of the ligand and the stability constants of the $\mathrm{Co}(\mathrm{II})$ metal ions. $\mathrm{H}_{2} \mathrm{~L}$ shown the highest DNA binding affinity and minimum inhibitory concentration (MIC) activity than complexes.

\section{References}

1. Ebrahimipour SY, Khabazadeh H, Castro J, Sheikhshoaie I, Crochet A, et al. (2015) cis-Dioxido-molybdenum (VI) complexes of tridentate ONO hydrazone Schiff base: Synthesis, characterization, X-ray crystal structure, DFT calculation and catalytic activity. Inorg Chim Acta 427: 52-61.

2. Suvarapu LN, Seo YK, Baek SO, Ammireddy VR (2012) Review on analytical and biological applications of hydrazones and their metal complexes. Journal of Chemistry 9: 1288-1304.

3. Crisalli P, Kool ET (2013) Importance of ortho proton donors in catalysis of hydrazone formation. Org Lett 15: 1646-1649.

4. El-Asmy AA, El-Gammal O, Radwan H, Ghazy S (2010) Spectrochimica Acta Part A: Molecular and Biomolecular Spectroscopy 77: 297-303.

5. Singh R, Jain P, Singh R (1982) Hydrazones as analytical reagents: a review. Talanta 29: 77-84.

6. Seleem HS, El-Inany GA, El-Shetar BA, Mousa MA, Hanafy FI (2011) The ligational behavior of an isatinic quinolyl hydrazone towards copper (II)-ions. Chem Cent J 5: 1.

7. Abdel-Wahab BF, Awad GE, Badria FA (2011) Synthesis, antimicrobial, antioxidant, anti-hemolytic and cytotoxic evaluation of new imidazole-based heterocycles. Eur J Med Chem 46: 1505-1511.

8. Abu-Surrah AS, Safieh KAA, Ahmad IM, Abdalla MY, Ayoub MT, et al. (2010) New palladium (II) complexes bearing pyrazole-based Schiff base ligands: Synthesis, characterization and cytotoxicity. Eur J Med Chem 45: 471-475.

9. Ajani OO, Obafemi CA, Nwinyi OC, Akinpelu DA (2010) Microwave assisted synthesis and antimicrobial activity of 2-quinoxalinone-3-hydrazone derivatives. Biorg Med Chem 18: 214-221.

10. Al-Said MS, Bashandy MS, Al-Qasoumi SI, Ghorab MM (2011) Anti-breast cancer activity of some novel 1,2-dihydropyridine, thiophene and thiazole derivatives. Eur J Med Chem 46: 137-141.

11. Aslam MAS, Mahmood S-U, Shahid M, Saeed A, Iqbal J (2011) Synthesis biological assay in vitro and molecular docking studies of new Schiff base derivatives as potential urease inhibitors. Eur J Med Chem 46: 5473-5479.

12. Cui Z, Li Y, Ling Y, Huang J, Cui J, et al. (2010) New class of potent antitumor acylhydrazone derivatives containing furan. Eur J Med Chem 45: 5576-5584.

13. Kaushik D, Khan SA, Chawla G, Kumar S (2010) N'-[(5-chloro-3-methyl-1phenyl-1H-pyrazol-4-yl) methylene] 2/4-substituted hydrazides: Synthesis and anticonvulsant activity. Eur J Med Chem 45: 3943-3949.

14. Edrees MM, Farghaly TA, El-Hag FA, Abdalla MM (2010) Antimicrobial, antitumor and $5 \alpha$-reductase inhibitor activities of some hydrazonoyl substituted pyrimidinones. Eur J Med Chem 45: 5702-5707.

15. Vogel Al (1991) Vogel's Textbook of Quantitative Chemical Analysis. 5th edn. Longmans, London.

16. Patai S (1970) Chemistry of the carbon-nitrogen double bond. Interscience New York.

17. Delley B (2002) Hardness conserving semilocal pseudopotentials. Phys Rev B: Condens Matter 66: 155125.

18. Modelling and Simulation Solutions for Chemicals and Materials Research (2011) Materials Studio, (Version 7.0), Accelrys software Inc., San Diego, USA.

19. Hehre WJ (1986) Ab initio molecular orbital theory. Wiley-Interscience.

20. Kessi A, Delley B (1998) Density functional crystal vs. cluster models as applied to zeolites. Int J Quantum Chem 68: 135-144.

21. Hammer B, Hansen LB, Nørskov JK (1999) Improved adsorption energetics within density-functional theory using revised Perdew-Burke-Ernzerhof functionals. Phys Rev B: Condens Matter 59: 7413-7421.

22. Matveev A, Staufer M, Mayer M, Rösch N (1999) Density functional study of small molecules and transition-metal carbonyls using revised PBE functionals. Int J Quantum Chem 75: 863-873.

23. Hawkey P, Lewis D (1994) Medical Bacteriology - A Practical Approach. Oxford University Press, United Kingdom.

24. El-Gammal O, Rakha T, Metwally H, El-Reash GA (2014) Synthesis, characterization, DFT and biological studies of isatinpicolinohydrazone and its Zn (II), Cd (II) and Hg (II) complexes. Spectrochimica Acta Part A: Molecular and Biomolecular Spectroscopy 127: 144-156.

25. Burres NS, Frigo A, Rasmussen RR, McAlpine JB (1992) A colorimetric microassay for the detection of agents that interact with DNA. J Nat Prod 55: 1582-1587.

26. Rakha T, Nawar N, Abu El-Reash G (1996) Transition Metal Complexes from $\mathrm{N}$-Anthranilamido-N'-benzoylthiocarbamide (H2ABTC). Synth React Inorg MetOrg Chem 26: 1705-1718.

27. Gup R, Kırkan B (2005) Synthesis and spectroscopic studies of copper (II) and nickel (II) complexes containing hydrazonic ligands and heterocyclic coligand. 
Citation: El-Reash YGA, Zaky R, Yaseen MA (2016) 2-(2-(2-Hydroxybenzyliden) Hydrazinyl)-2-Oxo-N-(Pyridine-2-Yl) Acetamide Complexes: Synthesis, Characterization and Biological Studies. Chem Sci J 7: 145. doi: 10.4172/2150-3494.1000145

Page 10 of 10

Spectrochimica Acta Part A: Molecular and Biomolecular Spectroscopy 62: 1188-1195.

28. Zaky R, Yousef T, Ibrahim K (2012) Co (II), Cd (II), Hg (II) and U (VI) O 2 complexes of o-hydroxyacetophenone [N-(3-hydroxy-2-naphthoyl)] hydrazone: physicochemical study, thermal studies and antimicrobial activity. Spectrochimica Acta Part A: Molecular and Biomolecular Spectroscopy 97: 683-694.

29. Chandra S, Jain D, Sharma AK (2009) EPR, mass, electronic, IR spectroscopic and thermal studies of bimetallic copper (II) complexes with tetradentate ligand, 1, 4-diformyl piperazine bis (carbohydrazone). Spectrochimica Acta Part A: Molecular and Biomolecular Spectroscopy 71: 1712-1719.

30. Beynon J (1960) Mass Spectrometry and its Applications to Organic Chemistry, Elsevier, Amsterdam.

31. Mitkina T, Fedin V, Llusar R, Sorribes I, Vicent C (2007) Distinctive unimolecular gas-phase reactivity of $[\mathrm{M}(\mathrm{en}) 2] 2+(\mathrm{M}=\mathrm{Ni}, \mathrm{Cu})$ dications and their inclusion complexes with the macrocyclic cavitand cucurbit [8] uril. J Am Soc Mass Spectrom 18: 1863-1872.

32. El-Ayaan U, Kenawy I, El-Reash YA (2007) Synthesis, thermal and spectral studies of first-row transition metal complexes with Girard-T reagent-based ligand. J Mol Struct 871: 14-23.

33. Tossidis I, Bolos C, Aslanidis P, Katsoulos G (1987) Monohalogenobenzoylhydrazones III. Synthesis and structural studies of Pt (II), Pd (II) and Rh (III) complexes of Di-(2-pyridyl) ketonechlorobenzoyl hydrazones. Inorg Chim Acta 133: 275-280.

34. Joseyphus RS, Dhanaraj CJ, Nair MS (2006) Synthesis and characterization of some Schiff base transition metal complexes derived from vanillin and $\mathrm{L}(+)$ alanine. Transition Met Chem 31: 699-702.

35. Lever BP (1984) 479

36. Su CY, Liao S, Cai YP, Zhang C, Kang BS, et al. (2000) Nickel(II) and cobalt(II) complexes with a mixed donor acyclic ligand bearing heterocyclic moieties as terminal groups. Transition Met Chem 25: 594-598.

37. Lever ABP (1968) Inorganic Electronic Spectroscopy. Elsevier, Amsterdam.

38. Moore JW, Pearson RG (1961) Kinetics and mechanism. John Wiley \& Sons, New York.

39. Hatakeyama T, Quinn F (1994) Fundamentals and applications to polymer science. J Therm Anal.

40. Maravalli P, Goudar T (1999) Thermal and spectral studies of 3-N-methylmorpholino-4-amino-5-mercapto-1, 2, 4-triazole and 3-N-methyl-piperidino- 4-amino-5-mercapto-1, 2, 4-triazole complexes of cobalt (II), nickel (II) and copper (II). Thermochim Acta 325: 35-41.

41. Yusuff KM, Sreekala R (1990) Thermal and spectral studies of 1-benzyl-2 phenylbenzimidazole complexes of cobalt (II). Thermochim Acta 159: 357-368.

42. Siddalingaiah AHM, Naik SG (2002) Spectroscopic and thermogravimetric studies on $\mathrm{Ni}$ (II), Cu (II) and Zn (II) complexes of di (2, 6-dichlorophenyl) carbazone. Journal of Molecular Structure: THEOCHEM 582: 129-136.

43. Chacko J, Parameswaran G (1984) Thermal decomposition kinetics of vanillidene anthranilic acid complexes of cobalt (II), nickel (II), copper (II) and zinc (II). J Therm Anal Calorim 29: 3-11.

44. El-Gammal OA (2010) Synthesis, characterization, molecular modeling and antimicrobial activity of 2-(2-(ethylcarbamothioyl) hydrazinyl)-2-oxo-Nphenylacetamide copper complexes. Spectrochimica Acta Part A: Molecular and Biomolecular Spectroscopy 75: 533-542.

45. Despaigne AAR, Da Silva JG, Do Carmo ACM, Piro OE, Castellano EE, et al. (2009) Copper (II) and zinc (II) complexes with 2-benzoylpyridine-methyl hydrazine. J Mol Struct 920: 97-102.

46. West DX, Swearingen JK, Valdés-Martínez J, Hernández-Ortega S, El-Sawa AK, et al. (1999) Spectral and structural studies of iron (III), cobalt (II, III) and nickel (II) complexes of 2-pyridineformamide N (4)-methylthiosemicarbazone. Polyhedron 18: 2919-2929.

47. El-Gammal O, Bekheit M, Tahoon M (2015) Synthesis, characterization and biological activity of 2-acetylpyridine-a-naphthoxyacetylhydrazone its metal complexes. Spectrochimica Acta Part A: Molecular and Biomolecular Spectroscopy 135: 597-607.

48. Govindarajan M, Periandy S, Carthigayen K (2012) FT-IR and FT-Raman spectra, thermo dynamical behavior, HOMO and LUMO, UV, NLO properties, computed frequency estimation analysis and electronic structure calculations on a-bromotoluene. Spectrochim Acta A Mol Biomol Spectrosc 97: 411-422.

49. Abu El-Reash GM, El-Gammal O, Ghazy S, Radwan A (2013) Characterization and biological studies on $\mathrm{Co}$ (II), $\mathrm{Ni}$ (II) and Cu (II) complexes of carbohydrazones ending by pyridyl ring. Spectrochim Acta A Mol Biomol Spectrosc 104: 26-34.

50. Pearson RG (1989) Absolute electronegativity and hardness: applications to organic chemistry. J Org Chem 54: 1423-1430.

51. Padmanabhan J, Parthasarathi R, Subramanian V, Chattaraj P (2007) Electrophilicity-based charge transfer descriptor. J Phys Chem A 111: 1358-1361.

52. Ghaly MA, El-Bendary ER, Shehata IA, Bayomi SM, Habib S (2012) Synthesis, antimicrobial activity, DNA-Binding affinity and molecular docking of certain 1 , 2, 4-triazolo [1, 5-a] pyrimidines as nalidixic acid isosteres. J Am Sci 8: 617-628. 